\title{
Hydrological change: reaping prosperity and pain in Australia
}

\author{
F.X. Dunin ${ }^{1}$, C.J. Smith ${ }^{2}$ and O.T. Denmead ${ }^{2}$ \\ ${ }^{1}$ CSIRO Plant Industry Private Bag No 5, PO Wembley WA 6914, Australia \\ ${ }^{2}$ CSIRO Land and Water PO 1666 Canberra, ACT 2611 Australia \\ Email for corresponding author: Frank.Dunin@csiro.au
}

\begin{abstract}
The adage: "There is no such thing as a free lunch", is relevant to land-use hydrology in Australia. Changes in land use to achieve greater productivity of food and fibre may have an adverse effect on the water balance and hence on the natural resource capital of a catchment. An altered regime of catchment outflow accompanies those land-use changes which, together with land degradation, impairs available water resources in quantity and quality and threatens enterprise sustainability, notwithstanding the initial improvement in productivity. Central to any hydrological change is an altered pattern of seasonal and annual water use by vegetation that has become modified in function with an amended transpiration fraction of daily evapotranspiration. In Australia, since measurement of evapotranspiration became feasible, the hydrological consequences of changes in land use have been determined, allowing the benefits in terms of plant productivity achieved through enhanced water use efficiency to be weighed against changed catchment outflows, diminished in either quantity or quality. Four case studies are presented as examples of ecological and hydrological changes: two deal with the upland forest environment and two with arable lowlands. In an upland eucalypt forest, following wildfire with subsequent regeneration from natural seedling establishment, substantial reduction in water yield occurred throughout a 50-year period of succession in the even-aged stand. In comparison, the effect of converting eucalypt forest to pine plantations was less detrimental to the yield of water from the catchments, with substantial growth increases over 30 years. In the lowlands, agricultural productivity, both as annual pasture and as crop, far exceeds that of natural perennial grassland and woodland. This increase in productivity comes not so much from any change to the yield of total water outflow but at the expense of water quality, compromised with increased material transport in suspension and solution resulting from accelerated erosion in association with outbreaks of soil salinity and acidity. The present study is aimed at optimising management to give plant production outcomes that ensure environmental protection through resource conservation. In the uplands, harvesting of water is the dominant consideration so that conservative management with limited plant productivity is sought. In the lowlands, the objective is to devise novel ecosystems with profitable plant production that exercises due control on outflow in maintaining the chemical and physical integrity of the edaphic environment.
\end{abstract}

Keywords: catchment area research

\section{Introduction}

Altering the balance of catchment outputs from water to food and fibre disturbs the ecological balance by influencing the rate of carbon turnover. Hydrological changes associated with this ecological disturbance then follow. Interventions, deliberate or inadvertent, prolonged or episodic, can modify the annual pattern of soil water dynamics. Interaction of this modified pattern with processes responsible for the gain, loss and transfer of soil water may alter outflow to provide tangible evidence for the response of a catchment undergoing change. Total outflow from a catchment comprises three constituent flows, overland flow, interflow or shallow lateral flows (short residence time with a half life of $<6$ months) and deep vertical drainage to recharge groundwater aquifers (generally long residence times with a half life of $>5$ years). The change can be expressed in terms of total outflow, in the proportions of the constituent fluxes, or in the water quality of these fluxes.

This view from an Australian watershed focuses on landscape elements considered, 30 years ago, to be in transition. Upland reaches under forest cover are contrasted with lowland areas under arable management with agricultural production. In these changes, the generality of original observations has been explored using the understanding gleaned from process studies, especially those involving direct measurement of catchment water use that comprise evaporation loss through interception and evapotranspiration (with components of direct evaporation from soil and of transpiration involving root water uptake).

The manipulation and conversion of vegetation changes 
the evapotranspiration. This direct cause-and-effect makes understanding evapotranspiration central to understanding hydrological change.

In a review of Australian catchment research, Boughton (1970) asserted that the increase in infiltration accompanying observed reductions in runoff resulted from the development of greater soil water deficits in surface soils; this condition had been induced by enhanced uptake of soil water that accompanies vigorous growth. Experimental confirmation of this claim was obtained through a process study on paired catchments that demonstrated that productivity gains from increased pasture growth reduced runoff through increased evapotranspiration without any change in the infiltration properties of sorptivity and hydraulic conductivity (Dunin, 1976). Ongoing study into evapotranspiration has sought a robust characterisation of water use that enables diversity in plant function and morphology to be expressed as variability in the annual pattern of water use. A ceiling daily evaporation rate is deemed to be an important distinguishing feature of ecosystems and is defined for each of the three component processes of water use, interception loss from vegetation $\left(\mathrm{E}_{\mathrm{T}}\right)$, direct evaporation from the soil surface $\left(\mathrm{E}_{\mathrm{S}}\right)$ and transpiration by vegetation $\left(\mathrm{E}_{\mathrm{U}}\right)$.

In the early 1960s, when McCulloch was applying an education in "natural philosophy" to advance scientific rigour in land use hydrology in equatorial East Africa, similar developments to address issues of land and water conservation were occurring in temperate Australia. Primary industry dominated Australian GNP and technological advances had lifted agricultural productivity and gross margins several-fold. Yet there was a price to pay in restoring land that had been scarred by erosion and also in combating emerging problems of solute mobilisation that were implicated in outbreaks of soil salinity and acidity. These forms of degradation cost the community dear in the impairment of the water resource through material transport in suspension and solution.

Conservation to tackle these issues had been in reclamation mode until the concept of the soil-plantatmosphere continuum was articulated by Philip (1957) and incorporated in a strategy of land management to achieve ecological stability through changes in the water balance proposed by Downes $(1958,1959)$. Downes argued that productive outcomes were possible with an optimal water balance that maintained the chemical and physical integrity of the soil by exercising control on the rate of ouflow discharge. A novel ecology to meet these aims must be predicated on annual patterns of water use to achieve optimal soil water extraction to regulate outflow within certain bounds, while enabling critical uptake for desired growth levels. Field data on rates of evapotranspiration are crucial to the development of such novel ecosystems. McCulloch's recognition of such a need to support forest hydrology was evidenced by his establishment of a long-term micrometeorological study of pine evapotranspiration at Thetford (see Stewart and Thom, 1973; Gash and Stewart, 1977; Stewart, 1988). It is ironic that Australia, with a renowned reputation in micrometeorology, had lagged in applying that discipline in the service of water resource management. Collaboration within Australia has now provided detailed water use and growth data across grassland, forest and agriculture. This information will be used to provide a background parametisation to approach the four case studies of perturbed ecology analysed here.

Forest communities occupy much of the upland reaches of the Great Australian Divide that separates coastal rivers in south-east Australia from the extensive inland system of the Murray-Darling Basin with vast areas of arable lowland. The forests are dominated by numerous species of the hardwood genus, Eucalyptus. These forests have been subject to selective logging, clear felling and fire (both prescribed and accidental). This investigation of the hydrological consequences of changes in land use presents two case studies of upland forest disturbance: regeneration of eucalypts following the severe wildfire of 1939 and clear felling of eucalypts for pine plantations. Similarly, two agricultural case studies are presented, where fertiliser inputs have contributed to ecological change in grassland in one case and to improved crop agronomy in the other. Contrasting growth responses in each case are associated with unexpected change to outflow and challenge the axiom that increased growth demands greater water use. Their selection is made because a counter-intuitive hydrological response in both cases has demanded resolution using the background understanding gained from previous process studies. Again, the parameter set is invoked to resolve the respective paradoxes.

\section{Theoretical considerations linking land use to hydrology}

\section{HYDROLOGICAL PERSPECTIVES}

This overview contrasts two landscape units that differ in topography and general function in the use of the basic resources of light, water and carbon for plant growth. In the pristine state, resident plant communities have adapted to the environment for a steady state condition termed hydrological equilibrium (Eagleson, 1982). The rate of plant functioning is synchronised with climatic inputs of water and energy and interacts with soil conditions to develop an outflow regime that poses little or no hazard to the 
persistence of the ecosystem. Characteristic flow patterns will evolve in different parts of the landscape and hydrological responses to perturbation can be expected to differ across the landscape.

Evergreen forest will be the climax vegetation when annual rainfall is high relative to energy inputs and there is adequate soil water supply for plant function throughout the year. Forests on the sloping terrain of the uplands of south-east Australia receive high rainfall due to orographic uplift of oncoming air, while lower temperatures at higher altitudes reduce the atmospheric demand for water. Hence, the forest ecosystem can be sustained even on the relatively shallow soils ( $<2 \mathrm{~m}$ deep) such as those often encountered along the Australian Divide. This combination of factors results in periods of soil water excess that translate into perennial streamflow, making the forest environment the dominant contributor to riverflow in temperate Australia. The mechanics of flow are distinctive and offer benefits for urban water supply.

On forested hillslopes, rainfall infiltrates freely (Dunin et $a l ., 1983$ ) into a medium rendered highly permeable by tree roots (Talsma and Hallam, 1979). A conservative rate of soil water uptake by forests (McNaughton and Jarvis, 1983) pre-disposes redistribution of moderate proportions of infiltrated water to recharge to shallow aquifers which service streamflow with quickflow (Hewlett and Hibbert, 1969); this rapid transmission of shallow groundwater in a conduit network scoured out over a historical sequence of events results from pressure build-up from soil water excess in the rooting zone. A by-product of this rapid turnover of water is a leaching fraction which maintains solute concentrations at a low level in streamflow - a basis for good quality water.

The Murray-Darling Basin is characterised by arable agriculture on terrain with undulating to flat relief. Over much of the riverine farmland annual rainfall is low $(<650 \mathrm{~mm})$, with a Mediterranean climate having abundant soil water in winter and spring. The natural ecosystems are dominated by perennial species, both grassy and woody (Moore, 1970). Woodland communities comprise evergreen overstorey species, such as acacias and eucalypts, widely spaced to enable sufficient light penetration to support an understorey of grasses and forbs. In some regions, woodlands give way to natural grassland dominated by a summer active perennial grass species, Themeda australis. The $\mathrm{C}_{4}$ pathway metabolism of this species demands tissue temperature in excess of $15^{\circ} \mathrm{C}$ before photosynthesis can proceed (Hatch et al., 1967) and so there is limited growth in winter and spring even when soil water is abundant. This community with winter dormancy will be compared with agricultural plant communities as an example of converted ecology forcing hydrological change.

In this semi-arid region, soils tend to be clay-based; the bulk density increases with depth and the hydraulic conductivity is low. Consequently, rainfall infiltration is confined largely to the rooting zone of the grassland. Overland flow is the major form of outflow, assisted in winter by the dormancy of the Themeda grass. Flow beyond the rooting zone, although irregular and infrequent, serves as an effective leaching fraction to recharge groundwater systems. With increasing aridity these outflow changes to surface-based flow is comparable to the Northern Hemisphere (Freeze, 1972).

Catchment outflow from natural grassland differs from that from forest because it originates as overland flow and it yields only some $5 \%$ of annual rainfall (Dunin, 1965). In contrast, forest with $1500 \mathrm{~mm}$ annual rainfall yields some $30 \%$ - exceeding the lowland value by more than an order of magnitude (Langford et al., 1980). Although the areal extent of the arable sector exceeds that of catchment forests by a factor of 2-3, its contribution to river flow is meagre. However, a lack of yield should not be mistaken for an absence of pollution hazard and the potential to impair water quality.

\section{CHARACTERISING WATER USE BY PLANT COMMUNITIES}

As a starting point to linking carbon and water fluxes, the rate of total water use $\left(\mathrm{E}_{\mathrm{T}}\right)$ is defined as a series of evaporative processes $\left(\mathrm{E}_{\mathrm{X}}\right)$ comprising interception loss $\left(\mathrm{E}_{1}\right)$ and the collective losses from soil $\left(\mathrm{E}_{\mathrm{U} / \mathrm{S}}\right)$ when the canopy is dry; these comprise losses due to direct evaporation from soil $\left(\mathrm{E}_{\mathrm{S}}\right)$ and that from root water uptake for transpiration through the leaves in the canopy $\left(E_{U}\right)$. Each of these processes is served by a water source $\mathrm{W}_{\mathrm{X}}$ and each has a specific capacity $\mathrm{W}_{\mathrm{I}(\mathrm{C})}, \mathrm{W}_{\mathrm{S}(\mathrm{C})}$ and $\mathrm{W}_{\mathrm{U}(\mathrm{C})} \equiv \mathrm{W}_{\mathrm{U} / \mathrm{S}(\mathrm{C})}$.

$$
\mathrm{E}_{\mathrm{T}}=\alpha \mathrm{E}_{\mathrm{S}}+(1-\alpha) \mathrm{E}_{\mathrm{I}}+(1-\alpha) \mathrm{E}_{\mathrm{U}}
$$

when $\mathrm{W}_{\mathrm{I}}>0, \mathrm{E}_{\mathrm{I}}>\mathrm{E}_{\mathrm{U}}=0$, and for $\mathrm{W}_{\mathrm{I}}=0, \mathrm{E}_{\mathrm{U}}>\mathrm{E}_{\mathrm{I}}=0$. The partitioning coefficient, $\alpha$ represents that fraction of area contributing to $\mathrm{E}_{\mathrm{T}}$ as direct evaporation from soil, while (1$\alpha)$ is the area with contributions from vegetation either wetted with intercepted rainfall or unwetted and subject to stomatal control of transpiration; $\alpha$ depends on leaf area index (LAI) and was devised to represent the proportion of $\mathrm{E}_{\mathrm{T}}$ occurring as $\mathrm{E}_{\mathrm{S}}$ (Denmead, 1998). The form of the relationship is equivalent to a partitioning of the available radiant energy between two sinks or stores that deliver water vapour to the atmosphere. This distribution of heat energy between sources involves $\mathrm{k}$, an empirical absorption 
coefficient. The proportion of available radiant energy that impinges on soil, $\alpha$, serves as a surrogate for the virtual area with direct evaporation from soil, while $(1-\alpha)$ represents the projected green canopy area achieving absorption of $>90 \%$ of available radiant energy to drive transpiration.

$$
\alpha=\mathrm{e}^{-\mathrm{kLAI}}
$$

The rate of water vapour flow to the atmosphere (Eqn. 2) is the lesser of two fluxes, the atmospheric demand, $\mathrm{E}_{0}$, and the capability of the given store to supply water vapour, $E_{\mathrm{x}}$, under the conditions prevailing. $\mathrm{E}_{0}$ has been a central issue in debate about atmospheric demand and the impact of demand on evaporative response (Denmead and Shaw, 1964, versus Ritchie, 1981). The FAO formulation of reference crop evapotranspiration (Allen et al., 1998) is useful in irrigation applications but, despite misgivings about an alternative solution for $\mathrm{E}_{0}$, the Priestley-Taylor formula, $\mathrm{E}_{\mathrm{P}-\mathrm{T}}$, has been selected here for its flexibility in dealing with seasonal variability in growth and energy supply in rainfed conditions.

$$
\mathrm{E}_{\mathrm{X}}=\min \left(\mathrm{E}_{0}, E_{X}\right)
$$

Capability is indicated as an evaporation response, $E_{\mathrm{X}}$, to available water in a given store at time $t, \mathrm{~W}_{\mathrm{x}(\mathrm{t})}$, in the schematic diagram, Fig. 1, with a distinctive form for each process to describe sequences of daily evaporation. To deal with temporal variability in energy inputs and with spatial variability in soil hydraulic properties, the respective responses are shown in normalised form using variables, $E_{\mathrm{X}} / \mathrm{E}_{\mathrm{P}-\mathrm{T}}$, and $\mathrm{W}_{\mathrm{X}(\mathrm{t})} / \mathrm{W}_{\mathrm{X}(\mathrm{C})}=\theta_{\mathrm{X}(\mathrm{t})}$.

The ramp form to describe transpiration response, $E_{\mathrm{U}}$, calls for a two-stage specification with a ceiling level to account for energy limitation and a falling stage when $\mathrm{W}_{\mathrm{U}(\mathrm{t})} / \mathrm{W}_{\mathrm{U}(\mathrm{C})}<$ $\theta_{\mathrm{U}(\omega)}$ reflects soil water limitation once a state of incipient soil water stress, $\omega$, has been reached. A constant value of $\theta_{\mathrm{U}(\omega)}$ across a range of $\mathrm{E}_{\mathrm{P}-\mathrm{T}}$ has been adopted in producing a unique response of the normalised transpiration relationship in accord with the analysis of Tuzet et al. (2003) that confirmed the daily response proposed by Ritchie (1981). The ceiling rate, designated as $\hat{U}_{\mathrm{U}}$, represents the average value of $E_{\mathrm{U}} / \mathrm{E}_{\mathrm{P}-\mathrm{T}}$ for the plateau sector when $1>\mathrm{W}_{\mathrm{U}(\mathrm{t})} / \mathrm{W}_{\mathrm{U}(\mathrm{C})}>$ $\theta_{\mathrm{U}(\omega)}$. Invariance of $E_{\mathrm{U}} / \mathrm{E}_{\mathrm{P}-\mathrm{T}}$ across this sector, although debated, has been assumed here on the basis that opposing effects apply during an initial rise in stomatal resistance; increases in canopy temperature in response to increased resistance introduce an elevated gradient in vapour pressure which results in an unperturbed transpiration rate. For $\mathrm{W}_{\mathrm{U}(\mathrm{t})} /$ $\mathrm{W}_{\mathrm{U}(\mathrm{C})}<\theta_{\mathrm{U}(\omega)}$,

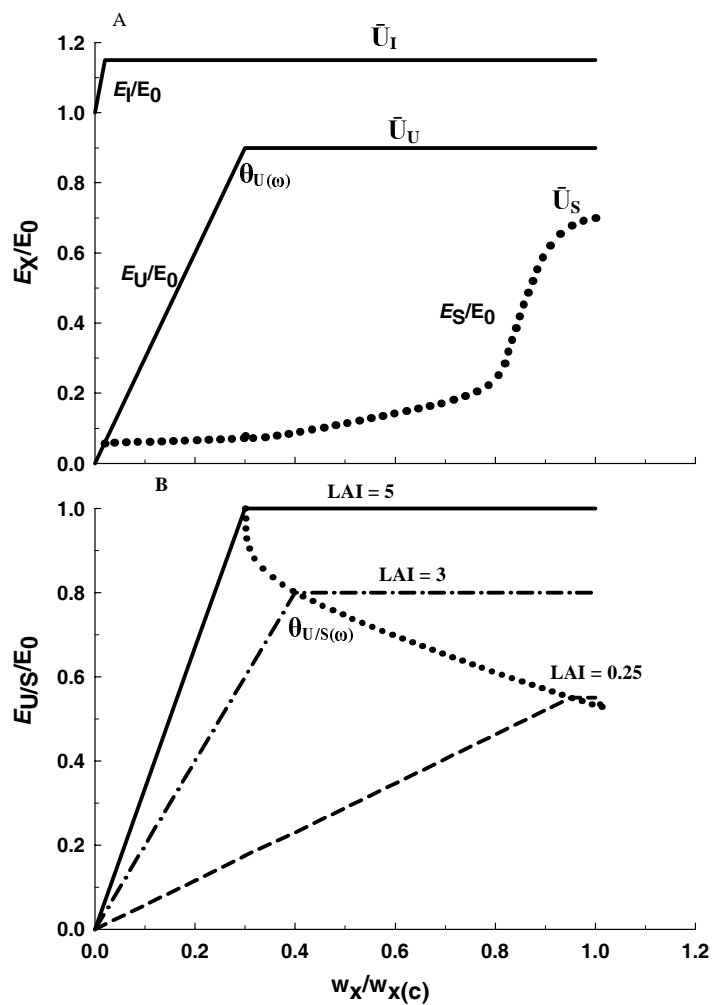

Fig. 1. A. Schematic diagram of evaporation response to changing soil water in root zone indicating different progressions for the normalized daily rate, $E_{X} / E_{P-T}$ in each of the constituent fluxes, $E_{P}, E_{U}$ and $E_{S}$ as well as in their respective upper limits $\hat{U}_{J} \hat{U}_{U}$ and $\hat{U}_{S} .{ }^{P}$. Normalised response of evapotranspiration, $E_{U / S} E_{P-T}$ to soil water changes by complex plant communities with canopies subject to variable area (LAI) either in space or time. The locus of points connecting the points of inflection for each response describes covariation in $\hat{U}_{U S}$ and $\theta_{U / S(\omega)}$ with changing LAI.

$$
E_{\mathrm{U}} / \mathrm{E}_{\mathrm{P}-\mathrm{T}}=\hat{U}_{\mathrm{U}}\left(\left(\theta_{\mathrm{U}(\omega)}-\left(\mathrm{W}_{\mathrm{U}(\mathrm{t})} / \mathrm{W}_{\mathrm{U}(\mathrm{C})}\right)\right) / \theta_{\mathrm{U}(\omega)}\right)
$$

describes the progressive reduction in transpiration as soil water reserves diminish. $E_{\mathrm{S}}$ response tends to be sigmoid, requiring specification for $\hat{U}_{S}$ and $\mathrm{W}_{\mathrm{S}(\mathrm{C})}$. This functional form, $E_{\mathrm{S}(\mathrm{t})}=\mathrm{f}\left(\mathrm{W}_{\mathrm{S}(\mathrm{t})}\right)$, is based on the power law relationship for steady state gain and loss of soil water (Philip, 1957, 1967),

$$
\Sigma E_{\mathrm{S}}=\mathrm{E}_{\mathrm{P}-\mathrm{T}} \hat{U}_{\mathrm{S}} \mathrm{t}^{1 / 2}
$$

where $\hat{U}_{\mathrm{S}}=E_{\mathrm{S}(1)}$ is the maximum daily rate of soil evaporation from a store, full to capacity, $\mathrm{W}_{\mathrm{S}(\mathrm{C})}$ on day 1 after replenishment. The derivative of this relationship yields $E_{\mathrm{S}(\mathrm{t})}$ to be matched to the corresponding water status of the store determined as

$$
\mathrm{W}_{\mathrm{S}(\mathrm{t})}=\mathrm{W}_{\mathrm{S}(\mathrm{C})}-\hat{U}_{\mathrm{S}}(\mathrm{t}-1)^{1 / 2}
$$

$\mathrm{W}_{\mathrm{S}(\mathrm{C})}$ is the water available to the plant in surface soil $\sim 25 \mathrm{~cm}$ 


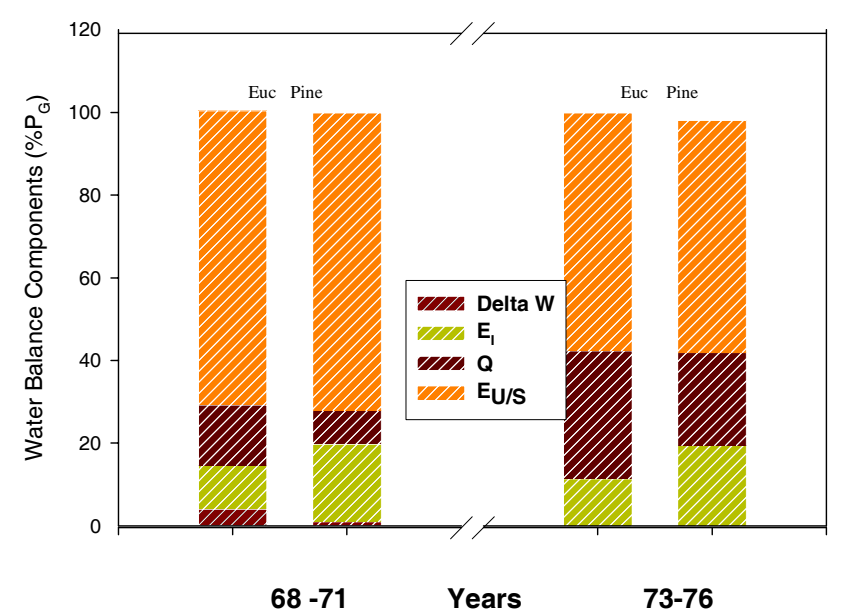

Fig. 2. Water balance comparison of eucalypt woodland with pine plantation at Lidsdale, N.S.W., with the two sets of paired catchments and with the individual components represented as a percentage of catchment rainfall.

deep for direct evaporation and is generally $<\mathrm{W}_{\mathrm{U}(\mathrm{C})}$. In Fig. $2 \mathrm{a}, 0.7=\hat{U}_{\mathrm{S}}<\hat{U}_{\mathrm{U}}<\hat{U}_{\mathrm{I}}>1.0$ applies; this distinguishes the upper bound for each form of evaporative loss. Values of $\mathrm{U}_{\mathrm{S}}$ generally fall within the range $0.3-0.7$ depending on the hydraulic properties of the upper soil horizon and can be rated on the basis of textural category.

Interception loss, $E_{\mathrm{I}}$, is characterised by enhanced rates with $\hat{U}_{\mathrm{I}}>1.0$, shown as a step function with an enhanced but constant rate at $\hat{U}_{\mathrm{I}}=1.15$ while $0<\mathrm{W}_{\mathrm{I}(\mathrm{t})}<\mathrm{W}_{\mathrm{I}(\mathrm{C})}$. At $\mathrm{W}_{\mathrm{I}(\mathrm{t})}$ $=0, \hat{U}_{\mathrm{I}}=\hat{U}_{\mathrm{U}}$, for transpiration to be re-initiated after adjustment to $\mathrm{W}_{\mathrm{U}(\mathrm{t}-1)}$ for infiltration gain from net rainfall input, $\mathrm{P}_{\mathrm{N}}=\mathrm{P}_{\mathrm{G}}-\mathrm{E}_{\mathrm{I}}$. Aerodynamic roughness is the major determinant of enhancement to increases in $\mathrm{E}_{\mathrm{I}} / \mathrm{E}_{0}$ with $\hat{U}_{\mathrm{I}}>$ 1.0 , the value of which is a function of canopy height. In the schematic diagram, the level of enhancement at $15 \%$ greater than $\mathrm{E}_{\mathrm{P}-\mathrm{T}}$ is typical of an agricultural crop $<1 \mathrm{~m}$ tall, while $\mathrm{W}_{\mathrm{I}(\mathrm{C})}$ ranges between 0-2 $\mathrm{mm}$. Agricultural plant communities with moderately turbulent regimes experience interception loss during sunlight from the interception store alone, indicating that interception losses during rainfall are absent or negligible. Generally, the daily quantity of interception loss is equal to or less than $\mathrm{W}_{\mathrm{I}(\mathrm{C})}$.

Forest trees, commonly $>10 \mathrm{~m}$, generate a highly turbulent atmospheric boundary layer with large eddies. This greater turbulence induces high $\hat{U}_{\mathrm{I}}$ that results from variable $\mathrm{E}_{\mathrm{I}} / \mathrm{E}_{0}$ as $1<\mathrm{E}_{\mathrm{I}} / \mathrm{E}_{0}<5$ while $\mathrm{W}_{\mathrm{I}}>0$. Variable enhancement of $\mathrm{E}_{\mathrm{I}}$ has been attributed to $\mathrm{E}_{\mathrm{I}} / \mathrm{E}_{0}=\mathrm{f}\left(\mathrm{W}_{\mathrm{I}} / \mathrm{W}_{\mathrm{I}(\mathrm{C})}\right)$ (Rutter et al., 1972). These features enhance the interception loss rates compared to short agricultural plant communities with detectable vapour fluxes during rainfall (Rutter,1967). The combination of a phase of interception depletion post-rainfall and one of continuing loss during rainfall has been described as a linear function of rainfall for the progress of cumulative interception loss during a rain event (Gash, 1979). The slope of this relationship, $\Omega$, can be robust across time scales for a given community such that an event-based value can be applied at the annual scale (Dunin et al., 1989) to simplify estimation of interception loss by forest and woodland communities.

The hydrological significance of the interception process may be gauged using the concept of additional vapour loss consequent on the imposition of an interception store (Rutter, 1968). Assuming complete infiltration of net rainfall $P_{N}$, soil water gain $\left(\mathrm{W}_{\mathrm{P}}\right)$

$$
\mathrm{W}_{\mathrm{P}}=\mathrm{P}_{\mathrm{N}}=\mathrm{P}_{\mathrm{G}}-\mathrm{E}_{\mathrm{I}}
$$

is compared with a notional gain $\left(\hat{W}_{P}\right)$ that assumes complete infiltration of gross rainfall, $\mathrm{P}_{\mathrm{G}}$, to be depleted only by transpiration operating at $\mathrm{U}_{\mathrm{U} / \mathrm{S}}$ for that post-rainfall period $(\delta \tau)$ with a wetted canopy,

$$
\hat{W}_{P}=\mathrm{P}_{\mathrm{G}}-\left(\mathrm{E}_{0^{*}} \hat{U}_{\mathrm{U} / \mathrm{S}} * \delta\right) .
$$

An estimate of this incremental loss due to interception $\left(\Delta \mathrm{W}_{\mathrm{I}}=\mathrm{W}_{\mathrm{P}}-\hat{W}_{P}\right)$ can be derived from known $\mathrm{E}_{\mathrm{I}}$ and the respective ceiling rates of interception loss, $\hat{U}_{\mathrm{I}}$, and that as evapotranspiration for a dry canopy, $\hat{U}_{\mathrm{U} / \mathrm{S}}$.

$$
\Delta \mathrm{W}_{\mathrm{I}}=\mathrm{E}_{\mathrm{I}}\left(\hat{U}_{\mathrm{I}}-\hat{U}_{\mathrm{U} / \mathrm{S}}\right)
$$

In the absence of measurements of $\mathrm{E}_{\mathrm{I}}$, estimates can be made using a distinction for forest and agricultural communities for a specified study interval, such as a season or a year with measured daily rainfall.

For forest, with a designated value of $\Omega$ as the interception coefficient for the given forest type,

$$
\mathrm{E}_{\mathrm{I}}=\Omega_{*} \Sigma \mathrm{P}_{\mathrm{G}(\mathrm{n})}
$$

where $\Sigma \mathrm{P}_{\mathrm{G}}$ is the accumulated value of daily gross rainfall for the specified interval with $n$ wet days. For an agricultural community with an interception capacity, $\mathrm{W}_{\mathrm{I}(\mathrm{C})}$, and a study interval with $\mathrm{x}$ wet days where $\mathrm{P}_{\mathrm{G}}>\mathrm{W}_{\mathrm{I}(\mathrm{C})}$ and an accumulated gross rainfall for those (n-x) wet days with $\mathrm{P}_{\mathrm{G}}$ $<\mathrm{W}_{\mathrm{I}(\mathrm{C})}$ designated as $\Sigma P_{G}^{\prime}$,

$$
\mathrm{E}_{\mathrm{I}}=\left(\mathrm{x}_{*} \mathrm{~W}_{\mathrm{I}(\mathrm{C})}\right)+\sum P_{G(\mathrm{n}-\mathrm{x})}^{\prime}
$$

Anticipating results, values have been assigned to the terms of Eqn. 3 to assess the role of interception in water balance issues of land use. For an agricultural crop of wheat, 
$\mathrm{E}_{\mathrm{I}}=50 \mathrm{~mm}$ has been assumed for seasonal interception (Leuning et al., 1994), $\hat{U}_{\mathrm{I}}=1.15$ (Dunin et al., 1978) and $\hat{U}_{\mathrm{U} / \mathrm{S}}=1.0$ (Dunin et al., 1999) to deduce that an increment of $7.5 \mathrm{~mm}$ of seasonal $\mathrm{E}_{\mathrm{T}}$ is denied to those soil water loss processes implicated in partitioning between water use and outflow. An explicit account for interception in agricultural communities hardly seems warranted. By contrast, the case for an account of forest interception loss is substantiated on the basis of a $\Delta \mathrm{W}_{\mathrm{I}}$ calculation of $105 \mathrm{~mm}$ in $1000 \mathrm{~mm}$ annual rainfall of which $150 \mathrm{~mm}$ is represented as interception loss (Dunin et al., 1988) and values of $\mathrm{j}_{\mathrm{I}}=1.50$ and $\hat{U}_{\mathrm{U} / \mathrm{S}}=0.8$ are deemed appropriate based on this reference and Rutter (1967). A lack of due account of $105 \mathrm{~mm}$ would mean that annual infiltration is overestimated to be expressed as a doubling in computed streamflow (Q) from a forest catchment with observed $\mathrm{Q} \equiv 0.1 \mathrm{P}_{\mathrm{G}}$.

The forest environment is complex, with botanical diversity and a layered structure with distinctive storeys; three are common for eucalypt forest. Partitioning $E_{U / S}$ through Eqn.(1a) is inappropriate as $\alpha$ is defined to deal with two different sinks of heat from available radiant energy: namely, soil and green vegetation. The range of heat sinks and their relationship to water sources within the forest canopy demand an elaborate specification for the disposition of energy which complicates analysis in the absence of measured fluxes for the individual processes. Instead, characterisation for $\mathrm{E}_{\mathrm{I}}$ and $\mathrm{E}_{\mathrm{U} / \mathrm{S}}$ alone can lead to reproducible results once the role of leaf area index (LAI) is defined to account for variation in $\hat{U}_{\mathrm{U} / \mathrm{S}}$ and $\theta_{\mathrm{U} /(\omega)}$. Co-variation of $\hat{U}_{\mathrm{U} / \mathrm{S}}$ and $\theta_{\mathrm{U} / \mathrm{S}(\omega)}$ with changing forest LAI is described in terms of co-ordinates along the locus of points connecting $\theta_{\mathrm{U}(\omega)}$ across the family of ramp functions, each designated with a specific LAI (Fig. 1b). These different functions, each conforming to The Law of Limiting Factors, are based on measured daily values across a range of eucalypt communities, each possessing a characteristic LAI that tends to be stable over a series of years unless catastrophic conditions prune the canopy (Dunin, 2002). This empirical characterisation is justified for a general description on the grounds that, over much of the LAI range, $\mathrm{E}_{\mathrm{U}}$ is the dominant determinant of the combined flux to account for a coherent progression in $\hat{U}_{\mathrm{U} / \mathrm{S}}$. The failure of $\mathrm{E}_{\mathrm{S}}$ to complement $\mathrm{E}_{\mathrm{U}}$ in attaining $\hat{U}_{\mathrm{U} / \mathrm{S}}=1.0$ at moderate to low values of $\mathrm{E}_{0}$ (unlike crops) can be attributed to significant mulch effects of litter on the soil surface in forest and woodland. A similar description is applicable for natural grassland where the summer growing season is typified by dynamics in green LAI, while still maintaining a substantial component of senescent standing biomass.

\section{CARBON/WATER LINKAGES}

Biological response, as growth rate M (g DM (standing biomass) $\mathrm{m}^{-2} \mathrm{~d}$ ), can be described in terms of transpiration rate, $\mathrm{E}_{\mathrm{U}}\left(\mathrm{mm} \mathrm{d}^{-1} \equiv \mathrm{kgH}_{2} \mathrm{O} \mathrm{m}^{-2} \mathrm{~d}\right)$ and its efficiency, $\mathrm{TE}(\mathrm{gDM} /$ $\mathrm{kg} \mathrm{H} \mathrm{H}_{2}$ ).

$$
\begin{aligned}
& \mathrm{M}=\mathrm{E}_{\mathrm{U} *} \mathrm{TE} \\
& \mathrm{TE}=(\mathrm{ITE} / \mathrm{D})_{*}(\mathrm{RUE} / \mathrm{J})
\end{aligned}
$$

where ITE is the intrinsic transpiration efficiency for carbon dioxide assimilation (A), an entity that involves scaling the assimilation ratio, $\mathrm{A} / \mathrm{E}_{\mathrm{U}}$, with the atmospheric humidity deficit, $\mathrm{D}$, to provide a nearly constant value during active growth; this applies across species with a common metabolic pathway $\left(\mathrm{C}_{4}\right.$ or $\left.\mathrm{C}_{3}\right)$ while temperature conditions are optimal $\left(\mathrm{T}_{\text {OPT }}\right)$ for the rate of conversion of assimilated $\mathrm{CO}_{2}$ to hexose (Rawson et al., 1977; Sadras et al., 1991). A value of $\sim 12 \mathrm{~g}$ $\mathrm{CO}_{2} /\left(\mathrm{kg} \mathrm{H}_{2} 0 / \mathrm{kPa} \mathrm{D}\right)$ applies for $\mathrm{C}_{3}$ species and a doubled value seems appropriate for $\mathrm{C}_{4}$ pathway species. Radiation use efficiency (RUE) is expressed as dry matter of standing biomass per unit of intercepted solar radiation. J, the assimilate energy quotient, refers to the mass of $\mathrm{CO}_{2}$ assimilated per unit of intercepted solar radiation. Both these energy-based descriptors have units of mass/energy intercepted by green biomass and imply unconstrained assimilation of $\mathrm{CO}_{2}$ and, hence, an absence of soil water stress. $\mathrm{J}$ is applied here with a value of $3.47 \mathrm{~g} \mathrm{CO}_{2} / \mathrm{MJ}$ intercepted solar radiation, derived on the basis of an energy requirement for $\mathrm{CO}_{2}$ fixation $\left(11.5 \mathrm{MJ} / \mathrm{kg} \mathrm{CO}_{2}\right)$ and the active radiation component for photosynthesis is represented as $4 \%$ of total solar radiation (slope of light response curves). RUE is the distinctive characteristic to define growth response for a plant species or community and other information involves time-averaged values for air temperature and humidity. Air temperature is needed to determine if the optimum range for metabolism applies in the study time interval; outside this optimal temperature window, some fractional value of ITE must be invoked. Temperature and absolute humidity of air at some reference height are required for solutions of D.

\section{DISTINGUISHING LAND USE FOR RESOURCE USE}

A set of characteristic features for each of three forms of land use has been derived from a detailed study of water use, growth and carbon assimilation in the respective plant communities (Table 1). Each set, comprising a common array of 11 entities, represents a summary of the foregoing theory in dealing with plant function through the interactive resource use of water and carbon; a further six entities are 
Table 1. Variation in critical features pertaining to variables of water use (WU) and transpiration efficiency TE across different forms of land use of regenerating natural forest (RF) natural grassland (NG) and cropping rotations with wheat (CR). Values presented are drawn from nominated literature except those in italics where estimates are made using principles outlined in those three references cited under 11 and 12 . The other unsupported information for $\mathrm{T}_{\mathrm{OPT}}$ is drawn from ecological and agronomic observation and $\mathrm{D}$ the average growing season vapour pressure deficit of the atmosphere is taken from local weather observation.

\begin{tabular}{|c|c|c|c|c|c|c|c|}
\hline Resource & $E / M$ & Entity & Units & $R F$ & $N G$ & $C R$ & Sources \\
\hline \multirow{13}{*}{$\begin{array}{l}\text { Water } \\
\mathrm{E}_{\mathrm{X}} \\
\text { Eqn.(1) } \\
\left(\mathrm{mm} \mathrm{d}^{-1}\right)\end{array}$} & \multirow[t]{3}{*}{$\mathrm{E}_{\mathrm{I}}$} & $\mathrm{W}_{\mathrm{I}(\mathrm{C})}$ & $\mathrm{mm}$ & 0.51 & 2.02 & $0-23$ & \multirow{13}{*}{$\begin{array}{l}{ }^{1} \text { Dunin et al., (1988), }{ }^{2} \text { Aston }(1979),{ }^{3} \text { Leuning } \\
\text { et al., (1994), }{ }^{4} \text { Rutter }(1967),{ }^{5} \text { Dunin and } \\
\text { Reyenga (1978), }{ }^{6} \text { Dunin et al.,(2001), } \\
{ }^{7} \text { Denmead et al., (1996) }{ }^{8} \text { Tuzet et al., (2003), } \\
{ }^{9} \text { Dunin et al., (1984), }{ }^{10} \text { Aston and Dunin } \\
(1980)\end{array}$} \\
\hline & & $\hat{\mathrm{U}}_{\mathrm{I}}$ & & 1.54 & 1.155 & 1.153 & \\
\hline & & $\Omega$ & $\%$ & 151 & $\mathrm{n} / \mathrm{a}$ & $\mathrm{n} / \mathrm{a}$ & \\
\hline & \multirow[t]{3}{*}{$\mathrm{E}_{\mathrm{S}}$} & $\mathrm{W}_{\mathrm{S}(\mathrm{C})}$ & $\mathrm{mm}$ & & & 326 & \\
\hline & & $\widehat{\mathrm{U}}_{\mathrm{S}}$ & & & & 0.76 & \\
\hline & & $\mathrm{k}$ & & & & 0.617 & \\
\hline & \multirow[t]{3}{*}{$\mathrm{E}_{\mathrm{U}}$} & $\mathrm{W}_{\mathrm{U}(\mathrm{C})}$ & $\mathrm{mm}$ & & & 1106 & \\
\hline & & $\hat{\mathrm{U}}_{\mathrm{U}}$ & & & & 0.98 & \\
\hline & & $\theta_{\mathrm{U}(\omega)}$ & $\mathrm{m}^{3} \mathrm{~m}^{-3}$ & & & 0.78 & \\
\hline & \multirow[t]{4}{*}{$\mathrm{E}_{\mathrm{U} / \mathrm{S}}$} & $\mathrm{W}_{\mathrm{U} / \mathrm{S}(\mathrm{C})}$ & $\mathrm{mm}$ & 2109 & 1405 & 1106 & \\
\hline & & $\hat{\mathrm{U}}_{\mathrm{U} / \mathrm{S}}$ & & 0.89 & 0.810 & 1.09 & \\
\hline & & $\theta_{\mathrm{U} / \mathrm{S}(\omega)}$ & $\mathrm{m}^{3} \mathrm{~m}^{-3}$ & 0.79 & 0.710 & 0.79 & \\
\hline & & LAI & $\mathrm{m}^{3} \mathrm{~m}^{-3}$ & 3.09 & $0-25$ & $0-46$ & \\
\hline Biomass & $\mathrm{TE}$ & ITE & $\mathrm{kPag} \mathrm{kg}^{-1}$ & 1211 & 2511 & 1211 & \multirow{4}{*}{$\begin{array}{l}{ }^{11} \text { Tanner and Sinclair (1984), } \\
{ }^{12} \text { Whitfield and Smith (1989), } \\
{ }^{12} \text { Sinclair and Muchow ( 1999) }\end{array}$} \\
\hline M & & RUE & g MJ & 0.6 & 0.8 & 1.412 & \\
\hline Eqn.(4) & & TOPT & ${ }^{\circ} \mathrm{C}$ & 25 & 30 & 15 & \\
\hline$\left(\mathrm{kg} \mathrm{m}^{2} \mathrm{yr}^{-1}\right)$ & & $\mathrm{D}$ & $\mathrm{kPa}$ & 1.2 & 1.6 & 0.8 & \\
\hline
\end{tabular}

nominated for cropping rotations (CR) for which partitioning for $\mathrm{E}_{\mathrm{U}}$ and $\mathrm{E}_{\mathrm{S}}$ is possible. The interaction in resource use is expressed through LAI dynamics with control on water use for its rate and its composition for $E_{U}$ that leads to determination of growth rate subject to environmental influences, through $\mathrm{T}_{\mathrm{OPT}}$ in setting growth period and $\mathrm{D}$ in regulating TE. Growing season is the time interval that comprises daylight conditions with canopy temperature varying within an optimal temperature window that enables metabolism of assimilated $\mathrm{CO}_{2}$ to hexose to proceed at a faster rate than respiratory requirements for maintenance. This condition is approximated simply as $\mathrm{Ta}=\mathrm{T}_{\mathrm{OPT}} \pm 10^{\circ} \mathrm{C}$ and these temperature conditions have been used to compile an average D for the growth period. Comparison across the data sets then offers insights into variation of critical features that will be encountered in the case studies given in Table 2 .

A phase difference in the pattern of water use is notable in comparing natural forest (RF) and natural grassland (NG) with agricultural cropping rotations (CR) (Dunin et al., 1999; Smith et al., 2000). $\mathrm{T}_{\mathrm{OPT}}$ accommodates seasonal differences by reflecting the timing of $\mathrm{EE}_{\mathrm{U}}$ dominance in $\mathrm{E}_{\mathrm{U} / \mathrm{S}}$. The early spring occurrence of peak $\mathrm{E}_{\mathrm{U} / \mathrm{S}}$ in $\mathrm{CR}$ (Sept/Oct) is consistent with daytime average temperatures of $15^{\circ} \mathrm{C}$ along Latitude $35^{\circ} \mathrm{S}$ in southern Australia, while peak $\mathrm{E}_{\mathrm{U} / \mathrm{S}}$ in Nov-Dec for the natural ecosystems, RF and NG, are reflected in the higher values for $\mathrm{T}_{\mathrm{OPT}}$ of $25^{\circ} \mathrm{C}$ and $30^{\circ} \mathrm{C}$ for these respective communities. Growing season length and timing are implied in $\mathrm{D}$ for determining TE regulation. Summer season activity by $\mathrm{NG}$ is indicated with the highest $\mathrm{D}$ value of $1.6 \mathrm{kPa}$ although this regulation is offset by a higher ITE typical of $\mathrm{C} 4$ plant communities. The intermediate $\mathrm{D}$ value of $1.2 \mathrm{kPa}$ for RG indicates year-round growth potential by eucalypt communities, although summer bias and a sinusoidal $\mathrm{E}_{\mathrm{U} / \mathrm{S}}$ progression coupled with that of solar radiation are consistent with prolonged growth. The lowest value of $\mathrm{D}$ as $0.8 \mathrm{kPa}$ for $\mathrm{CR}$ denotes the temperate growing season for annual crops, May to November, with high TE that is instrumental in levels of seasonal growth of $10-15 \mathrm{t} \mathrm{ha}^{-1}$ of wheat biomass to be comparable with the annual growth of young eucalypt forest from an extended growth season with double the rainfall. This higher growth rate of wheat is attributable to its $\hat{U}_{\mathrm{U} / \mathrm{S}}$ value of 1.0 that is the maximum amplitude of all three of the annual patterns. The lowest amplitude occurs with NG whose $\hat{U}_{\mathrm{U} / \mathrm{S}}$ value of 0.8 can be limited in summer periods of infrequent rainfall to result in the lowest annual productivity of $2 \mathrm{t} \mathrm{ha}^{-1}$ (Groves, 1967). An intermediate capacity of plant available water, $\mathrm{W}_{\mathrm{U} / \mathrm{S}(\mathrm{C})}$, in NG was insufficient to temper effects of rainfall deficiency on growth, notwithstanding high TE. By contrast, high growth rates of $\mathrm{CR}$ were not perturbed greatly by low 
Table 2. Salient features involved in each case study indicating primary impact of intervention on hydrology with changed values (bold) together with values of associated unperturbed aspects. The outcome of retrospective analysis to maintain consistency between hydrological and ecologic change through Eqn. (4) is shown as variation in those critical features designated in italics. Units for each feature as shown in Table 1 are retained here unless specified as $\%$ of rainfall $\mathrm{P}(\mathrm{mm})$ with subscripts to indicate average annual over the study period (AAS), long term average annual (LTAA) and seasonal total for study crops (SEAS).

\begin{tabular}{|c|c|c|c|c|c|c|c|c|c|c|c|c|}
\hline \multirow[t]{2}{*}{$\begin{array}{l}\text { Case } \\
\text { Study }\end{array}$} & \multicolumn{4}{|l|}{ Outputs } & \multicolumn{5}{|c|}{$\begin{array}{c}\text { Perturbed entities \& relevant } \\
\text { characteristics }\end{array}$} & \multicolumn{3}{|c|}{$\begin{array}{l}\text { Environmental } \\
\text { conditions }\end{array}$} \\
\hline & Q/P (\%) & W & $\mathrm{E} / \mathrm{P}(\mathbf{0})$ & $\Omega$ & $\mathrm{T}_{\mathrm{OPT}}$ & RUE & $\hat{\mathrm{U}}_{\mathrm{U} / \mathrm{S}}$ & $\hat{U}_{I}$ & $\mathrm{~W}_{\mathrm{I}(\mathrm{C})}$ & $\mathrm{D}$ & $\mathrm{P}_{\mathrm{AAS}}$ & \\
\hline Pine & 8.3 & 0.9 & 71.9 & 0.19 & 15 & 0.75 & 0.8 & & 0.8 & 1.2 & 870 & \\
\hline Euc & 14.2 & 0.3 & 71.2 & 0.12 & 25 & 0.65 & 0.8 & & 0.3 & 1.2 & & \\
\hline $\begin{array}{l}\text { R Ash } \\
\text { M Ash }\end{array}$ & $\begin{array}{l}37.5 \\
75.0\end{array}$ & $\begin{array}{l}1.5 \\
0.43\end{array}$ & $\begin{array}{l}72.5 \\
20.6\end{array}$ & $\begin{array}{l}\text { LAI } \\
\mathbf{2 . 0} \\
\mathbf{3 . 5}\end{array}$ & $\begin{array}{l}\text { RUE } \\
0.5 \\
0.4\end{array}$ & $\begin{array}{l}\hat{\mathrm{U}}_{\mathrm{s}} \\
0.7 \\
0.2\end{array}$ & $\begin{array}{l}\hat{\mathrm{U}}_{\mathrm{U} / \mathrm{S}} \\
1.0 \\
0.4\end{array}$ & & & $\begin{array}{l}1.0 \\
1.0\end{array}$ & $\begin{array}{l}P_{\text {LTAA }} \\
1600\end{array}$ & \\
\hline NG & 5.0 & 2.2 & 0.94 & $\begin{array}{l}\mathrm{T}_{\mathrm{OPT}} \\
\mathbf{3 0}\end{array}$ & $\begin{array}{l}\text { RUE } \\
0.9\end{array}$ & $\begin{array}{l}\text { LAI } \\
0-2\end{array}$ & $\begin{array}{l}\hat{\mathrm{U}}_{\mathrm{U} / \mathrm{S}} \\
1.0\end{array}$ & $\mathrm{~W}_{\mathrm{I}}$ & $\begin{array}{l}\text { ITE } \\
25\end{array}$ & 1.5 & $\begin{array}{l}P_{\text {AAS }} \\
520\end{array}$ & \\
\hline IP & 0.5 & 6.3 & 0.96 & $\begin{array}{l}12.5 \\
\text { LAI }\end{array}$ & $\begin{array}{l}0.85 \\
\mathrm{E}_{\mathrm{U}}\end{array}$ & $\begin{array}{l}0-3 \\
\hat{U}_{\mathrm{U} / \mathrm{S}}\end{array}$ & $\begin{array}{l}0.7 \\
\text { ITE }\end{array}$ & $\begin{array}{l}50 \\
\mathrm{TE}\end{array}$ & $\begin{array}{l}12 \\
\text { RUE }\end{array}$ & 0.7 & $\mathrm{P}_{\mathrm{SEAS}}$ & $\mathrm{T}_{\mathrm{OPT}}$ \\
\hline $\begin{array}{l}\mathrm{WC}(\mathrm{N} 0) \\
\mathrm{WC}(\mathrm{N}+)\end{array}$ & $\begin{array}{l}22.3 \\
19.7\end{array}$ & $\begin{array}{l}1.52 \\
1.01\end{array}$ & $\begin{array}{l}83.9 \\
95.2\end{array}$ & $\begin{array}{l}0-4 \\
0-3\end{array}$ & $\begin{array}{l}145 \\
209\end{array}$ & $\begin{array}{l}0.8 \\
0.8\end{array}$ & $\begin{array}{l}12 \\
12\end{array}$ & $\begin{array}{l}7.0 \\
7.0\end{array}$ & $\begin{array}{l}1.34 \\
1.34\end{array}$ & $\begin{array}{l}0.66 \\
0.66\end{array}$ & 417 & $\begin{array}{l}15 \\
15\end{array}$ \\
\hline
\end{tabular}

$\mathrm{W}_{\mathrm{U} / \mathrm{S}(\mathrm{C})}$ in a seasonal regime of low $\mathrm{E}_{0}$. RF with conservative $\hat{U}_{\mathrm{U} / \mathrm{S}}$ accompanied by high $\mathrm{W}_{\mathrm{U} / \mathrm{S}(\mathrm{C})}$, has important properties for ecosystem stability under high rainfall through sustained but moderate growth. In such an environment, significant proportions of the rain are released regularly from the root zone to become perennial streamflow and creating a reliable water harvest.

These considerations allow differentiation of land use, in terms of a suite of critical features including biological rhythm and water use. The purpose of this approach is to gain understanding that will enable restoration of the resource base to a sustainable production level. The approach entails selection of a subset of salient features implicated in change and an assumption of their magnitude of change in each of the four case studies. This information is applied to deconvolute the rainfall/runoff process to articulate the critical flow pathways that contribute to total outflow from the ecosystem. The changed water use driving hydrological change is then assessed for its consistency with observed changes in plant productivity. Table 2 contains the information on water use and the other features subject to change in the specified case study. Also included are retrospective analyses based on consistency between changed production and water use achieved using Eqn. (4).

\section{Case studies of hydrological change}

\section{FOREST MANAGEMENT}

Forest management ranges from clear felling to a policy of minimal intervention designed expressly to protect water quality. Both case studies presented here deal with removal of mature forest: the first was a deliberate conversion of mature forest into pine plantations while in the second, wildfire destroyed a mature forest reserved exclusively for water supply. In the first case study, between 1950 and 1980, mature eucalypt forest with a history of selective logging was clear-felled and replaced with plantations of Pinus radiata to overcome a national shortfall in softwood for paper production. The second case study relates to the wildfire of Black Friday (Friday, January 13, 1939) which devastated the vegetation over a set of catchments which, since 1886 , had been dedicated to the urban water supply for Melbourne and were excluded from timber production and general public access. This was the most significant event in the history of fire ecology of temperate Australia.

The first Australian study of hydrological response to change in forest species was in Lidsdale State Forest, $130 \mathrm{~km}$ WNW of Sydney at altitude 975 m (Smith et al., 1974). In replicated paired catchments, the water used by dry sclerophyll forest was compared, in separate study periods of between 2.5 to 3 years, with that of $\sim 35$-year old plantations of Pinus radiata. Each period was scaled to an annual average for each component of the water balance 
Table 3. Water balance components, scaled for annual rate, $\mathrm{mm} \mathrm{yr}^{-1}$, from Lidsdale State Forest, to compare pine catchments with a eucalypt control catchment in two separate studies.

\begin{tabular}{lcccc}
\hline \multirow{2}{*}{ Period } & \multicolumn{2}{c}{ 17 Oct 1968-28 April 1971 } & \multicolumn{2}{c}{$1974-1976$} \\
Catchment & Pine \#2 & Eucalypt \#6 & Pine \#1 & Eucalypt \#6 \\
Precipitation, $\mathrm{P}_{\mathrm{G}}$ & 871 & 895 & 842 & 870 \\
Interception, $\mathrm{E}_{\mathrm{I}}$ & 163 & 95 & 183 & 99 \\
Nett rainfall, $\mathrm{P}_{\mathrm{N}}$ & 708 & 800 & 659 & 771 \\
Runoff, Q & 72 & 127 & 190 & 269 \\
Soil water change, $\Delta \mathrm{W}$ & 9 & 35 & -3 & 1 \\
Evapotranspiration, $\mathrm{E}_{\mathrm{U} / \mathrm{S}}$ & 627 & 638 & 472 & 501 \\
\hline
\end{tabular}

(Table 3) using data from the relevant experimental catchments at the Lidsdale site (Pilgrim et al., 1982). Contrast and consistency in the individual components are apparent, both between study periods and between plant communities, and this is emphasised with a representation of each component as a proportion of the catchment rainfall.

Variation in annual gross rainfall, $\mathrm{P}_{\mathrm{G}}$, was small between catchments and between study periods. Rainfall distribution must have differed between periods to cause $\mathrm{Q}_{6}$ (eucalypt control catchment) to be doubled in the later period as was the case with pine catchments $\mathrm{Q}_{1}$ and $\mathrm{Q}_{2}$. There was less runoff from the pine catchments. The runoff difference between pine and eucalypt catchments was $\mathrm{Q}_{6}-\mathrm{Q}_{\mathrm{I}}=$ $55 \mathrm{~mm}$ while the later value was $\mathrm{Q}_{6}-\mathrm{Q}_{2}=79 \mathrm{~mm}$; this constituted an overall difference $(67 \mathrm{~mm})$ as $7.7 \%$ of the time-averaged rainfall of the three catchments $(870 \mathrm{~mm})$. This value corresponded well with interception loss differences of $-68 \mathrm{~mm}$ and $-84 \mathrm{~mm}$ between catchments, an average value of $8.7 \%$ for proportionate interception loss between pines and eucalypts that may be deemed to be time invariant at the site. These results are qualitatively consistent with the greater stature of pines over the eucalypt stand (31 compared to $15 \mathrm{~m}$ ); this increased aerodynamic roughness and enhanced evaporation during rain. At the same time, a $50 \%$ difference in basal area (12 to $19 \mathrm{~m}^{2} \mathrm{ha}^{-1}$ ) increased interception capacity from estimates of $0.5 \mathrm{~mm}$ for the eucalypt to $0.8 \mathrm{~mm}$ for the pine. These determinations accord with a more recent generalisation for greater interception loss by pines over eucalypts at a given site, based on a review of Australian data (Feller, 1979). The magnitude of the difference may be stated as $0.10<\Omega$ (EUC) $<0.25$ and $\Omega(\mathrm{PINE})=\Omega(\mathrm{EUC})+0.10$, assuming sufficient stature has been attained to ensure that a linear description as $E_{\mathrm{I}}=\mathrm{f}\left(\mathrm{P}_{\mathrm{G}}\right)$ applies.

Runoff reduction was accounted for solely as a result of increased interception by pines relative to eucalypts, given that evaporative losses by $\mathrm{E}_{\mathrm{U} / \mathrm{S}}$, defined for conditions of a dry canopy, were comparable between communities (Smith et al., 1974). This claim was substantiated in the later period when measurements in catchments 2 and 6 implied that the additional water use by enhanced interception loss is associated with the greater biomass production of pines over eucalypts. Leuning et al., (1994) deduced that carbon gain can proceed in crops while $\mathrm{W}_{\mathrm{I}}>0$ and that the productive component of water use nominated as $\mathrm{E}_{\mathrm{U}}$ must incorporate interception losses. For forest, interception loss only during sunlight would qualify for inclusion in productive water use, so $30 \%$ of total $E_{I}$ was incorporated because $30 \%$ of forest interception loss was observed to occur during daylight near Bateman's Bay, $200 \mathrm{~km}$ south-east of Lidsdale (Dunin et al., 1988). A value of $25 \mathrm{~mm}$ has been derived as the differential interception component to be incorporated as productive water use. Combined with a TE value of $2.1 \mathrm{~g} \mathrm{~kg}^{-1}$ (using $\mathrm{D}=1.2 \mathrm{kPa}$ and $\mathrm{RUE}=0.75$ from Table 2), a value of $0.05 \mathrm{~kg} \mathrm{~m}^{-2} \mathrm{yr}^{-1}$ is derived to represent only $10 \%$ of the difference in growth rates between eucalypts and pines at Lidsdale as 0.3 and $0.9 \mathrm{~kg} \cdot \mathrm{m}^{-2} \mathrm{yr}^{-1}$ respectively (Lambert, 1979). Clearly, comparing $\mathrm{E}_{\mathrm{U} / \mathrm{S}}$ between forest communities is satisfactory for assessing hydrological controls on flow but it masks important differences for developing growth differences, presumed to be in the partitioning of $\mathrm{E}_{\mathrm{U} / \mathrm{S}}$ as well as in seasonal differences for metabolic function which confers advantages in TE for pines over eucalypts.

Vast tracts of mature forest of Eucalyptus regnans were devastated in 1939 in Melbourne's water supply catchments (termed the Maroondah catchment group $60 \mathrm{~km}$ north-east of Melbourne) in 1939. There followed a regeneration phase with an even-aged juvenile stand raised from seed in the initial phase, development of which had been conditioned by fire for germination and by light for seedling growth. The species exists as a series of pure stands in niches of high soil water availability along the soil catenary sequence (kraznosem) between the watershed or divide and the catchment outlet; species abundance ranged between 15 to $50 \%$ of catchment vegetation across the set of five catchments, with annual rainfall between 1000 and $2000 \mathrm{~mm}$. Post-1939, the juvenile regrowth varied from 24 
to $88 \%$ cover as replacement for mature E. regnans. The rest of the catchment vegetation comprises a small proportion of rain forest vegetation, often as understorey, and a further two components of wet sclerophyll eucalypt forest. Although aspect has a role in the distribution of these eucalypt species, one of these components is E.delegatensis, a fire-sensitive species of lower stature than E. regnans but given the same common name of mountain ash. A mixed species component of fire resistant species occupies the drier end of the soil water spectrum and their abundance becomes dominant as catchment rainfall approaches $1000 \mathrm{~mm}$. The recovery from the 1939 fire by the mixed species component has been almost complete due to vegetative propagation endowed by an epicormic storage organ, a common strategy among the numerous eucalypt species. E. regnans is renowned as the world's tallest hardwood, with mature stands commonly in the range 50-75 m tall, while individual species have heights $>100 \mathrm{~m}$. The attainment of such heights can introduce transmission resistance to sap flow and slow transpiration in mature stands, an aspect of plant/water relations to be considered later.

Evidence for a distinctive response of mountain ash forest to fire was provided by Langford (1976) with a statistical analysis and a model to describe streamflow reduction below the pre-1939 levels. This response was counter-intuitive based on generalisations for forest clearing with a phase of increased streamflow prior to stabilisation as re-vegetation progressed to restore the initial water balance (Bosch and Hewlett, 1982). Brown (1972) reported this type of hydrological response to fire for a mixed eucalypt community with a five-year phase to stability in a sub-alpine region at Yerongabilly along the Divide in south-east Australia. Langford devised a precise multiple-regression relationship for average depression in water yield ( $\Delta \mathrm{Q}-\mathrm{mm}$ ) over a period of 20 years (1944-1964), using as dependent variables the percentage of regrowth of E. regnans $\left(\mathrm{SP}_{\mathrm{REG}}\right)$ and of the mixed species component $\left(\mathrm{SP}_{\mathrm{ME}}\right)$.

$$
\Delta \mathrm{Q}=153+1.79 \mathrm{SP}_{\mathrm{REG}}-2.29 \mathrm{SP}_{\mathrm{ME}}
$$

Thus, water yield volume reductions as high as $30 \%$ can be associated directly with the regrowth of E. regnans; this suggests much higher consumptive use by the juvenile counterpart over the mature form. The term relating to mixed species cover was interpreted as a surrogate for catchment rainfall with a negative sign to reflect reduced sensitivity of hydrological response to regrowth as catchment rainfall became lower; that accords with increasing $\mathrm{SP}_{\mathrm{ME}}$. This insight has prompted a range of studies in stochastic hydrology and plant physiology, seeking to clarify the issue of declining urban water supply.

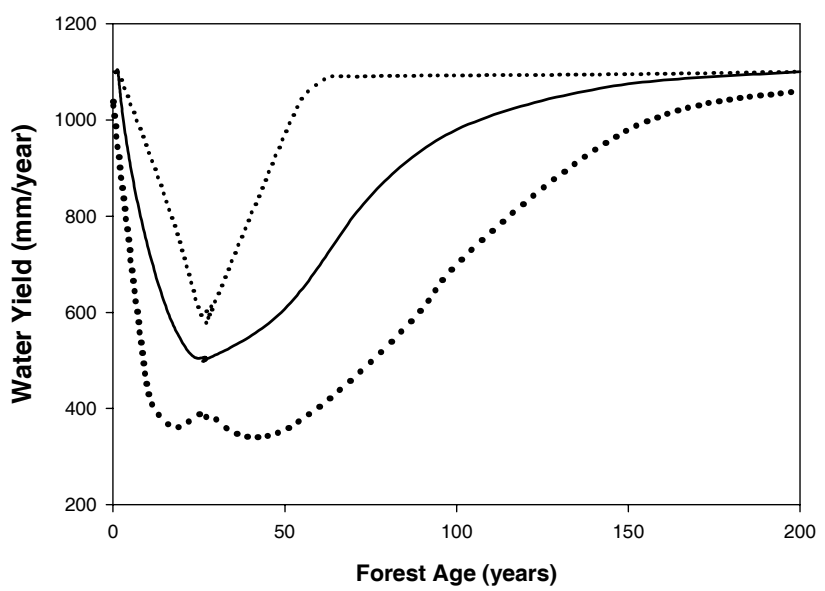

Fig. 3. The generalised Kuczera curve describing water harvest decline (with 90\% confidence limits), normalized for an average annual rainfall of $1600 \mathrm{~mm}$, with forest age in catchments having $100 \%$ composition as mountain ash (After Watson et al.,1999).

A development of Eqn. (5) has been devised with a statistical fitting procedure to the 40 -year record of postburn streamflow data from the Maroondah catchments to describe ecological succession in the ash forest with a time series of annual discharge (Kuczera, 1987). Two distinguishing features, the time to and the magnitude of minimum annual flow, are specific for a given catchment response determined largely by the amount of ash regrowth after the 1939 wildfire. Figure 3, designated as the generalised Kucerza curve, describes annual flow with age of regrowth, adjusted for variation around average annual rainfall, taken here to be $1600 \mathrm{~mm}$, for a catchment composed solely of ash forest (Watson et al., 1999). This has a response time of 27 years for an approximate 50\% reduction in yield which equates to $600 \mathrm{~mm}$ as the maximum change in water use between active regrowth and mature forest. Kucerza cautioned the accuracy of statistical description for the recovery phase of streamflow during succession towards maturity, indicated as being after 2040 . This phase is clearly critical for operational management of forest and prompted the deterministic approach of Watson et al. (1999) to describe the annual series of streamflow yield for the post-fire succession. This approach was predicated on the dynamics of LAI for a forest age sequence spanning a century to account for the effective control on evapotranspiration processes. This surrogate approach to stomatal function during forest succession has been facilitated by a coherent relationship between cross-sectional area of sapwood and canopy LAI. However, for ash forest progressing towards maturity, the trend for increasing crosssectional area is interrupted with reductions in sapwood area, partly due to tree thinning but also apparent on an individual tree basis (Dunn and Connor, 1993; Jayasuriya et al., 1993). 
At this stage of reducing sapwood, departure from a unique response in the sapwood area/LAI relationship is apparent with a retreat from a constant ratio to a falling value with time of sapwood area/LAI (Watson et al., 1999). This decline suggests a change in stomatal function for greater control that extends beyond the scope of the influence of falling LAI to conserve soil water. A similar argument has been mounted from Karuah, New South Wales, where a phase of pronounced streamflow reduction has occurred in the aftermath of forest clearing of experimental forested catchments with average rainfall ranging between 1475 and $1750 \mathrm{~mm}$ (Cornish and Vertessy, 2001). These communities are dominated by E. saligna and E. laevopinea; the rapid water use in the regrowth phase resembles E. regnans with a phase of reduced streamflow in the early stages of forest succession. Direct evidence for an approximate threefold difference in $\mathrm{E}_{\mathrm{U}}$ between mature and juvenile stands of $E$. sieberi (Roberts et al., 2000) adds weight to the claim that profligacy in resource use during regrowth may well be a general feature of a range of eucalypt communities.

An independent approach to evaluating the changing rate of water use during succession involves an inverse solution of Eqn. (4) based on the rate of regrowth reported for different stages of succession after burning (Brooks and Turner, 1964; Langford, 1976). For a 25-year old ash stand at pole stage, a height increase of $1.25 \mathrm{~m} \mathrm{y}^{-1}$ can be rated as the equivalent of $1.5 \mathrm{~kg} \mathrm{~m}^{-2} \mathrm{y}^{-1}$ for the rate of dry matter accumulation in above-ground biomass (Attiwill, 1979). This growth is assumed to result from continuous functioning of the canopy over an annual period subject to average vapour pressure deficit (VPD) of $1.0 \mathrm{kPa}$. An average canopy leaf area of LAI $=3.5$ is applied at the pole stage (Watson et al., 1999) with appropriate stand characteristics taken from Table 2 ( $\mathrm{RUE}=0.5, \Omega=0.2$ ) to determine the yearly value of TE $=1.7 \mathrm{~g} \mathrm{~kg}^{-1}$ in Eqn. (4) to derive the quantity of $880 \mathrm{~mm}$ of evaporated water that is associated with carbon gain. This quantity is deemed to comprise annual $\mathrm{E}_{\mathrm{U}}$ along with a fraction of total interception loss that occurs in sunlight during canopy drying; $30 \%$ of annual $\mathrm{E}_{\mathrm{I}}=\Omega \mathrm{P}_{\mathrm{G}}=320 \mathrm{~mm}$, represents $\sim 100 \mathrm{~mm}$ to be deducted for determining $\mathrm{E}_{\mathrm{U}}$ as $780 \mathrm{~mm}$. Transpiration is assumed to operate at ceiling levels throughout the year in this humid environment with $\hat{U}_{\mathrm{U}}=0.9$, leaving $10 \%$ of available radiant energy to be disposed of as $\mathrm{E}_{\mathrm{S}}$ with $\hat{U}_{\mathrm{s}}=$ 0.7 representing an annual value of $60 \mathrm{~mm}$; justification is based on Denmead (1984) who noted short-term equilibrium evaporation rates $\left(\equiv \hat{U}_{\mathrm{S}}=0.79\right)$ from the litter-covered forest floor underneath Pinus ponderosa near Canberra. An annual total of $1160 \mathrm{~mm}$ for annual $\mathrm{E}_{\mathrm{T}}$ compares favourably with a water balance determination of $\sim 1100 \mathrm{~mm}$ for regrowth communities $<40$ years old (Langford et al., 1980).
This supports application of the procedure for mature conditions where computation is complicated by the greater uncertainty in characterisation caused by increased diversity.

A 100 year-old mature forest can be rated for height increase as $0.18 \mathrm{~m} \mathrm{yr}^{-1}$ (Langford, 1976) with a stand LAI $=2.0$ (Watson et al., 1999). Conversion to dry matter productivity involves scaling with the previous ratio of dry matter/height, subject to adjustment for an effective doubling in basal area of the stand. An annual growth increment of $0.43 \mathrm{~kg} \mathrm{~m}^{-2} \mathrm{yr}^{-1}$ is applied with an annual TE $=1.4 \mathrm{~g} \mathrm{~kg}^{-1}$ to derive $310 \mathrm{~mm}$ of growth-effective evaporative loss that comprises an uptake component $(260 \mathrm{~mm})$ and a fractional interception loss taken to be $16 \%$ in this case $(50 \mathrm{~mm})$ due to different canopy architecture with similar LAI between overstorey and understorey. Variation in RUE down to $0.4 \mathrm{~g} \mathrm{MJ}^{-1}$ was applied to accommodate greater maintenance respiration for the 100 year stand. $\mathrm{E}_{\mathrm{S}}=70 \mathrm{~mm}$ is derived from an energy supply to the soil surface as $36 \%$ of that at canopy level for $\hat{U}_{\mathrm{s}}=0.2$ because of mulch effects and reduced aerodynamic conductance of dense understorey. Annual $\mathrm{E}_{\mathrm{T}}$ for mature forest is determined as $650 \mathrm{~mm}$, assuming constancy of $\mathrm{E}_{\mathrm{I}}$ between age classes. These considerations add up to a variation in annual water use of $510 \mathrm{~mm}$ during succession and support contentions for streamflow reduction by $\sim 600 \mathrm{~mm}$ at 25 years after burning of mature stands of ash forest.

\section{AGRICULTURAL DEVELOPMENT}

Two case studies of agricultural development involving hydrological changes are summarised in Table 2, with indications of perturbations to salient characteristics that have resulted from management of vegetation for food and fibre.

Natural perennial grassland $v$ improved annual grassland The first case study of paired experimental catchments compares the ecological and hydrological consequences of conversion of natural grassland to introduced annual pasture in receipt of phosphatic fertiliser, a practice that gained widespread acceptance in undulating arable country from $\sim 1955$ (Dunin and Downes, 1962). In its natural state, this land comprised both woodland and grassland (Moore, 1970) with moderate rainfall and a Mediterranean type climate. Addition of fertiliser with trace elements, particularly molybdenum, generated vigorous growth of the annual pasture, with a threefold increase in productivity of the clover/grass mix over the natural perennial grassland at this site. An accompanying reduction in overland flow (Table 4) from 26 to $3 \mathrm{~mm}$ was a major limitation to this burgeoning grazing enterprise in hill country (de Laine and Vasey, 1961). 
Table 4. Results of a paired catchment experiment at Bacchus Marsh, Victoria, using averaged data from the 4-year post treatment period to compare the catchment response under natural grassland (NG) with that using annual exotic pasture (IP) of subterranean clover and Wimmera rye grass (after Dunin, 1976).

\begin{tabular}{llcc}
\hline Item & Units & $N G$ & $I P$ \\
\hline Av rainfall & $\mathrm{mm} \mathrm{yr}^{-1}$ & 524 & 524 \\
Av runoff & $\mathrm{mm} \mathrm{yr}^{-1}$ & 26 & 3 \\
Peak discharge & $\mathrm{mm} \mathrm{hour}^{-1}$ & 2.4 & 10.4 \\
Sorptivity $\left(\theta_{0}=0.2\right)$ & $\mathrm{cm} \mathrm{minute}^{-1 / 2}$ & 0.21 & 0.24 \\
$\mathrm{E}_{\mathrm{T}} / \mathrm{E}_{\mathrm{O}}(\mathrm{sp})$ & $\mathrm{mm} \mathrm{mm}^{-1}$ & 0.98 & 1.07 \\
$\theta_{0}-$ Initial soil water & & & \\
$\mathrm{E}_{\mathrm{O}}(\mathrm{sp})-$ Evap from Aust sunken pan $\sim 0.9 \mathrm{E}_{\mathrm{P}-\mathrm{T}}$ & \\
\hline
\end{tabular}

Moreover, the lost water harvest failed to reduce peak discharge with respective rainfall equivalent values of 2.4 and $10.4 \mathrm{~mm} \mathrm{hr}^{-1}$. When cleared of its native vegetation, erosion rates accelerated from much of this terrain (Downes, 1958), while erosion hazard, coupled with peak discharge as opposed to total quantity of overland flow, increased due to an absence of protective vegetation in the warm seasonal conditions associated with convective storms of high rainfall intensity. Further, outbreaks of dryland salinity have affected both water resources and land capability (Downes, 1972; Peck, 1978). The driving force for secondary salinity is accelerated deep drainage (Bettanay et al., 1964), which is expressed by differences between communities in the regime of subsoil water content; a temporal pattern under natural perennial grassland with regular summer oscillation was indicative of uptake at this soil depth compared with annual pasture having an oscillation that is attenuated and irregular to reflect drainage for groundwater recharge (Fig. 4). This paradox of enhanced growth leading to an impaired resource base must be resolved to address the pervasive issue of enduring prosperity for agricultural enterprises.

A phase difference in the biological rhythm between communities is expressed in terms of the climatic variables in Table 2 that deal with $\mathrm{T}_{\mathrm{OPT}}$ for seasonal function and its associated D, influencing TE. In this comparison of plant communities, these features affect growth and infiltration issues. A high optimal temperature for natural grassland ensures summer growth activity by $\mathrm{C}_{4}$ pathway metabolism in the dominant species, Themeda australis. This biochemical attribute endows the high ITE that is assured in summer in temperate Australia but is lost when the temperature drops below $15^{\circ} \mathrm{C}$ (Hatch and Slack, 1966). Hence, summer growth progresses to a senescent sward in winter; this leads to a distinctive hydrological regime of a

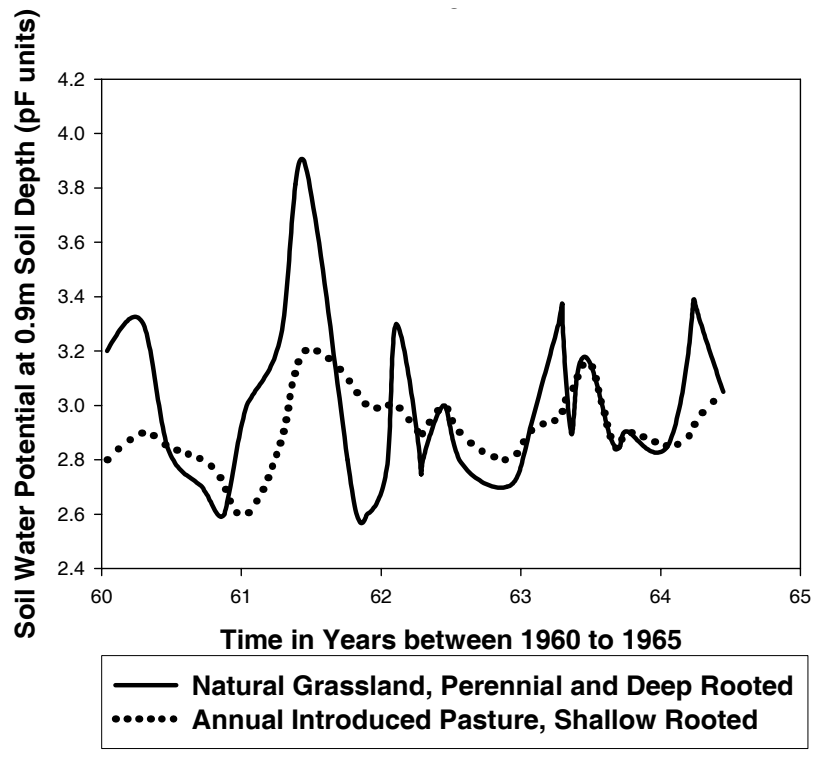

Fig. 4. Dynamics in subsoil water potential (expressed in pF units $\Psi$ $\left.\log _{10}(\mathrm{~cm})\right)$ at $0.9 \mathrm{~m}$ soil depth for paired catchments, near Bacchus Marsh, with natural grassland designated as deep rooted species and annual improved pasture shown as shallow rooted species (after Dunin, 1970).

dominant discharge of clean water from overland flow and a small component of deep drainage serving as a leaching fraction. Summer activity of the dominant perennial grass ensures effective control of deep drainage through exhaustive soil water uptake from the root zone each summer (Fig. 4). A significant proportion of the sward consists of dead material across all seasons; this acts as an effective mulch which suppresses $\mathrm{E}_{\mathrm{S}}$ when grazing pressure is light (Groves, 1974). Diminished uptake in winter and spring due to limited green leaf area (limited $\mathrm{C}_{3}$ pathway species exist in the sward) combines with suppressed $\mathrm{E}_{\mathrm{S}}$ to maintain low soil water deficits in surface soil during a period with abundant soil water. Infiltration rates are low and so a reasonable fraction of rain becomes runoff ( $5 \%$ in Table 3$)$. Limited redistribution of this soil water gain is characterised by a depth profile of diminishing drainage flux within the root zone. A subsoil scavenged of soil water in the previous summer restricts vertical drainage at the base of the root zone in most seasons. The annual introduced pasture species have a temperate character, with $\mathrm{T}_{\mathrm{OPT}}$ adapted to make growth in winter and spring through uptake that permits high rates of infiltration with an attendant reduction in runoff. Not all the infiltration is retained for soil water extraction despite high values for $\hat{U}_{\mathrm{U} / \mathrm{S}}$. The opportunity for exploiting infiltration gain is diminished by a root zone that is truncated compared with the perennial grassland and there is higher frequency of deep drainage events to increase recharge to groundwater. Following this seasonal change 
in growth pattern, the discharge has been altered from overland flow to vertical drainage; species change involves replacement of a dominant summer perennial with temperate annual exotics.

Environmental degradation has accompanied this seasonal shift in growth activity in two ways. With perennial grassland lightly grazed, erosion is low and this enables year-round protection to discharge clean water. Vigorous summer growth enhances the protective grass cover to withstand erosion hazards imposed by peak discharge after the intense rainfalls associated with summer thunderstorms. Annual pasture, by comparison offers little protection to accelerated erosion even though annual runoff is much less but peak discharge rates are not mitigated. The dominant outflow changes to deep drainage, causing accelerated groundwater recharge to an aquifer network with low discharge rates; the resultant rise in water table levels is accompanied by salt in transition, which has a negative effect on both land capability and water quality.

Convential wheat cropping vs. crop management with supplemental $N$ fertiliser

The second example evaluates a contemporary management of crop agronomy that has been responsible for significant increase in the national wheat harvest over the past two decades (Hamblin and Kyneur,1993). Two fields, each of 5 ha, were used for a comparative water balance study (Table 5 ). Yield was enhanced by addition of nitrogen $(\mathrm{N})$ as urea and equivalent to $100 \mathrm{~kg}(\mathrm{~N}) \mathrm{ha}^{-1}$ prior to tillering when soil water levels were high on August 6,1993 (60 days after sowing). Significant increases of $50 \%$ in above ground biomass (10.1 and $15.2 \mathrm{t} \mathrm{ha}^{-1}$ ) (Table 5, Fig. 5b) and $80 \%$ in grain yield (3.8 and $6.8 \mathrm{t} \mathrm{ha}^{-1}$ ) were achieved. (Smith et al., 1998; Smith et al., 2000). Crop improvement was accompanied by a marginal increase of $47 \mathrm{~mm}$ in water use
( $\equiv 12 \%$ of the respective seasonal totals of 350 and $397 \mathrm{~mm}$ ) that translated into the development of an even smaller difference of $32 \mathrm{~mm}$ in the soil water deficit at harvest (Table 5). The resultant difference between treatments in seasonal drainage from the root zone is minor at $11 \%$ (Table 5, Fig. 5a); 1993 seasonal drainage as $\sim 20 \%$ of the seasonal rainfall ranks as approximately three times the 15-year average observed at this site for cropping conditions and an order of magnitude greater than under natural vegetation (Walker et al., 2002). Unlike the previous example in undulating terrain, deep drainage has been the dominant form of outflow in this flat terrain with $3 \%$ slope. An examination of the detailed time series for the seasonal course of a suite of variables relevant to growth and the water balance follows in seeking a resolution for the inconsistencies of substantial growth increments achieved without exercising drainage control and without great amounts of additional water use.

The pattern of cumulative rainfall diverged from that of total water use by both treatments $\mathrm{E}_{\mathrm{T}(\mathrm{N} O)}$ and $\mathrm{E}_{\mathrm{T}(\mathrm{N}+)}$ until the first week of October to indicate a phase of soil water excess with episodes of deep drainage (Fig. 5a). During this phase of abundant soil water, energy limits the rate of water use to $<3 \mathrm{~mm} \mathrm{~d}^{-1}$ resulting in $\mathrm{E}_{\mathrm{P}-\mathrm{T}}=\mathrm{E}_{\mathrm{U} / \mathrm{S}} \approx \mathrm{E}_{\mathrm{S}}$. Despite marked differences in LAI, the patterns of $\mathrm{E}_{\mathrm{T}(\mathrm{N})}$ and $\mathrm{E}_{\mathrm{T}(\mathrm{N}) \mathrm{f}}$ pre-October are comparable (Fig. 5b) to account for the similar drainage response observed between crops. However, in the postSeptember period when $3<\mathrm{E}_{\mathrm{T}}<6 \mathrm{~mm} \mathrm{~d}^{-1}$, convergence of $E_{T}$ to $P_{G}$ reflects the development of soil water deficits in both crops at the expense of drainage. Greater convergence of $\mathrm{E}_{\mathrm{T}(\mathrm{N}+)}$ to $\mathrm{P}_{\mathrm{G}}$ (Fig. 5a) indicates how the N-enhanced crop with greater $\mathrm{LAI}(\mathrm{N}+)$ exercises superior control of soil water flow in the root zone in this phase of high atmospheric demand. This greater control was expressed in terms of $11 \mathrm{~mm}$ less in seasonal drainage and even more so in terms of a greater deficit of $32 \mathrm{~mm}$ at harvest. Any drainage control

Table 5. Water balance components for 1993 growing season at Wagga Wagga, New South Wales, to compare treatment effects of supplemental nitrogenous fertilizer ( $\mathrm{N} 0$ and $\mathrm{N}+$ ) on wheat water use, ET, and constituent processes of $\mathrm{E}_{\mathrm{U}}$ and $\mathrm{E}_{\mathrm{S}}$. Seasonal Water Balance at Wagga Wagga, May 20-Nov 25, $1993(\mathrm{~mm})$

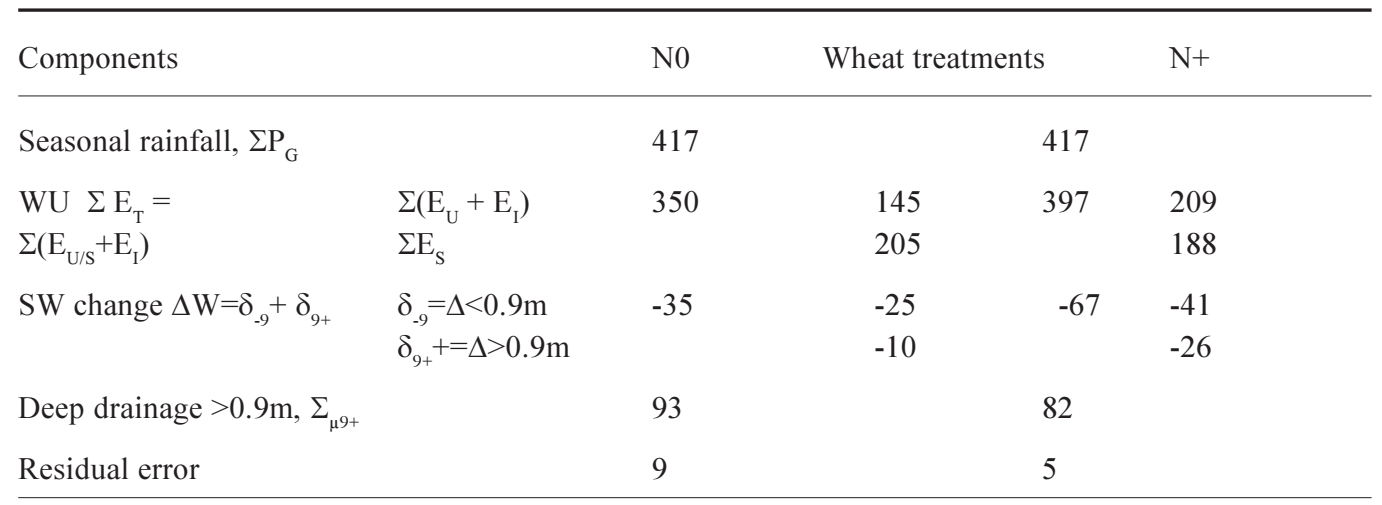


A

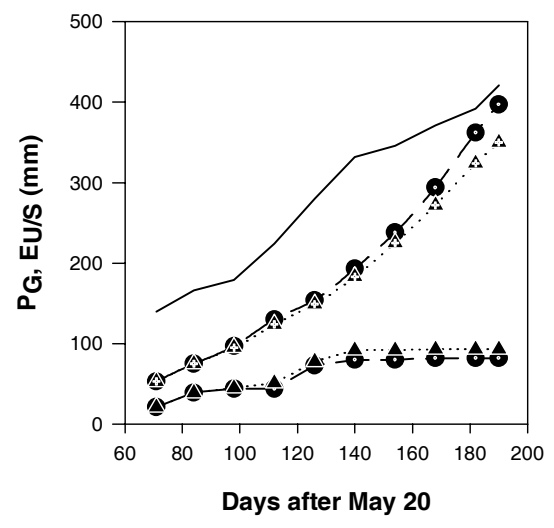

$\mathrm{B}$

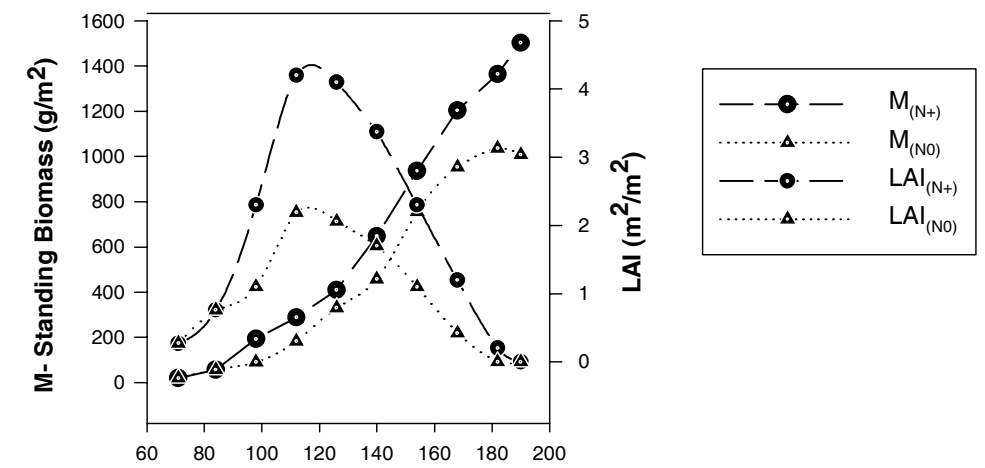

Days after May 20

Fia 5 C

C

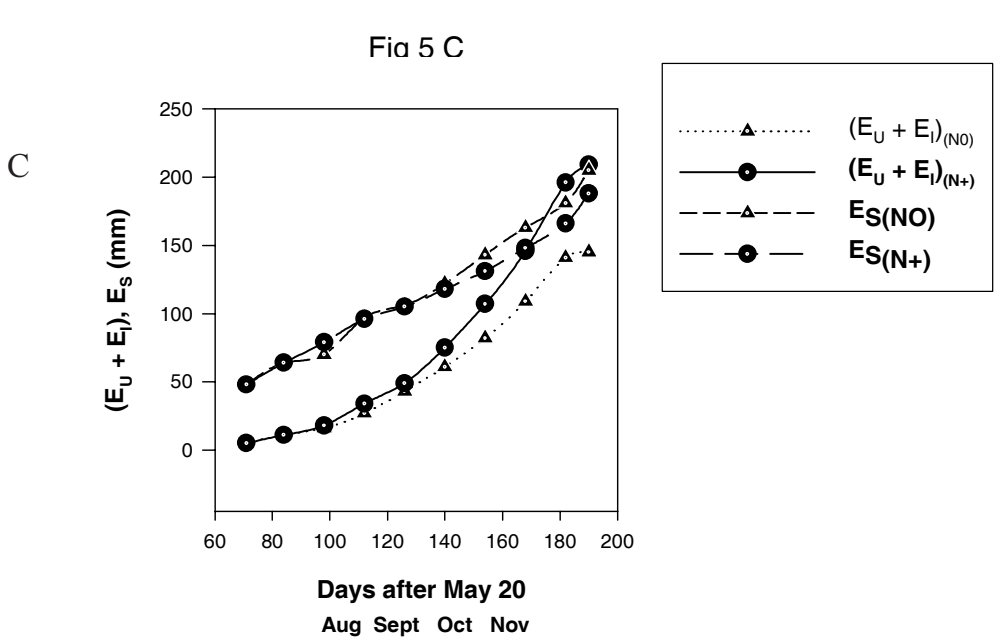

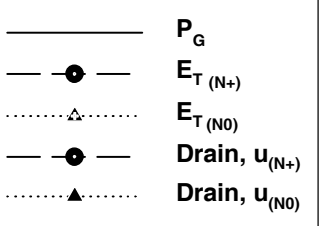

$\mathrm{E}_{\mathrm{T}(\mathrm{NO})}$
Drain, $\mathbf{u}_{(\mathrm{NO})}$

Fig. 5. A. Seasonal progression at Wagga Wagga in 1993 for cumulative rainfall $\left(P_{G}\right)$, total water use ( $E_{T N 0}$ and $\left.E_{T N++}\right)$ and drainage below $0.9 m$ for two wheat crops $\left(\mu_{N O)}\right.$ and $\left.\mu_{(N+}\right)$ with variation in application of supplemental nitrogenous fertilizer, $N 0$ and $N^{+}$, respectively. B. Seasonal course of cumulative standing biomass ( $M_{\text {and }}$ and $M_{\text {N }}$ ) and leaf area index (LAI and LAI ) of both crops. C. Seasonal course of cumulative transpiration plus interception loss $\left(\left(E_{U}+E_{\gamma_{N O}}\right.\right.$ and $\left(E_{U}+E_{Y_{N+}}\right)$ and direct evaporative loss from soil $\left(E_{S_{(N O)}}\right.$ and $\left.E_{\left.S_{(N+}\right)}\right)$ from both crops.

arising from this enhanced soil water extraction will be postponed until the subsequent season.

The patterns of cumulative transpiration plus interception loss, $\left(\mathrm{E}_{\mathrm{U}}+\mathrm{E}_{\mathrm{I}}\right)$ are offset from those of $\mathrm{E}_{\mathrm{T}}$ by $40-50 \%$ (Fig. $5 c)$. The seasonal total for $\left(E_{U}+E_{I}\right)_{(N+)}$ exceeds that for $\left(E_{U}\right.$ $\left.+\mathrm{E}_{\mathrm{I}}\right)_{(\mathrm{No})}$ by $64 \mathrm{~mm}$ whereas those for $\mathrm{E}_{\mathrm{T}}$ differ by $47 \mathrm{~mm}$.
The greater soil water uptake in treatment $\mathrm{N}_{+}$is driven by greater LAI but a compensating effect to suppress $\mathrm{E}_{\mathrm{S}}$ through greater shading has meant that the combined soil water extraction for both evaporative processes in this treatment is tempered by $17 \mathrm{~mm}$. The comparison of seasonal soil water decrement (Table 5) indicates that a $32 \mathrm{~mm}$ difference 
is contributed by a lower soil water loss to drainage from the root zone in treatment $\mathrm{N}_{+}$. A potential soil water deficit created by the requisite uptake of $64 \mathrm{~mm}$ for additional growth has been halved at harvest time due to the interacting influences of the increased growth to conserve soil water in the profile. Agronomic benefit achieved through greater uptake is not translated commensurately into hydrological control on flow processes.

Hydrological response as uptake for growth is summarised in the double mass curve (Fig. 6) describing the seasonal growth as a function of cumulative transpiration. The overall $\mathrm{TE}$ is remarkably similar between treatments at $7.11 \pm 0.16 \mathrm{~g}$ $\mathrm{DM} / \mathrm{kg} \mathrm{H}_{2} \mathrm{O}$. Over the course of the season, both treatments followed a similar two-stage progression; in the early season, the enhanced phase of TE relative to the overall seasonal value is followed by a phase of convergence on to the final value. This shows that more growth was achieved through greater LAI and, hence, higher seasonal transpiration without any significant impact of $\mathrm{N}$ on TE. The greater LAI was accomplished through sustained ceiling rates for longer than in the control treatment (Table 2). Although this lack of TE response to $\mathrm{N}$ continues to be debated in agronomic circles, there is a precedent for the role of $\mathrm{N}$ in stimulating growth without changing the respective rates for carbon assimilation and transpiration. Wong et al. (1979) demonstrated that greater photosynthetic capacity caused by higher $[\mathrm{N}]$ in the canopy was accompanied by higher stomatal conductance. Greater rates of resource use delivered faster growth through greater carbon assimilation, balanced by a corresponding increase in transpiration.

Recourse to a simple description of growth as a function of water use and its efficiency has become commonplace to account for a wide range of crop growth response in terms

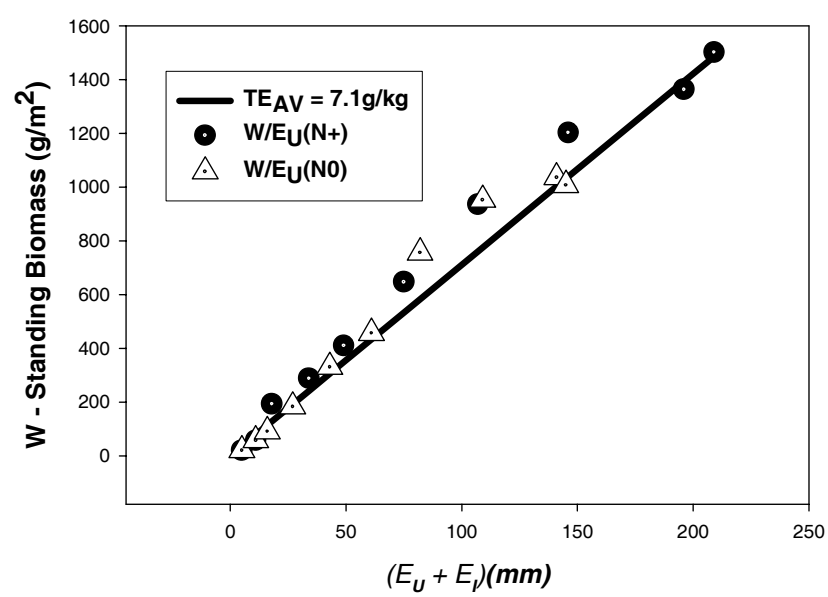

Fig. 6. Double mass plotting of cumulative standing biomass with cumulative transpiration and interception loss. The seasonal average of transpiration efficiency, $T E_{A V}$, is superimposed for reference. of water use factors; such an approach deems that the full array of edaphic factors that contribute to variability in productivity is implicated to influence either the quantity of water use or its efficiency for conversion into harvestable product (de Witt, 1959; Passioura, 1972; Tanner and Sinclair, 1984). This case study is a timely reminder that water relationships offer a convenient linkage between the water and carbon cycles. The impact of elevated $[\mathrm{N}]$ in the canopy derived from fertiliser was captured with increased LAI that was expressed as increased seasonal transpiration. The additional soil water uptake necessary to achieve a $50 \%$ increase in growth is explainable through Eqn. (4) (From Table 2, TE $\left.=7.0 \mathrm{~g} \mathrm{~kg}^{-1},{ }_{*} 64 \mathrm{~mm} \equiv 4.5 \mathrm{tha}^{-1}\right)$. The hydrological consequence on soil water flow of this improved agronomy has been modified in its magnitude and deferred in its timing. Incremental uptake of $64 \mathrm{~mm}$ translates into an equivalent seasonal decrement in soil water of $32 \mathrm{~mm}$; such a reduction in deep drainage would be unlikely to occur before the following crop season and then only if there were sufficient rainfall to overcome the soil water deficit and generate drainage flow.

\section{Towards integrated catchment management}

This review of four case studies of hydrological change emphasises how catchment management must seek an acceptable balance between water resources and plant productivity for food and fibre. A shift in either direction can impair the resource base and jeopardise the long-term viability of the management strategy. Too much plant production can deny water outflow altogether and risks salt accumulation in the root zone, so that agricultural productivity will diminish. Alternatively, excessive water outflow can degrade the edaphic environment with flooding and erosion and so may impede a critical plant function that controls outflow in quantity and quality. These considerations set limits to ecological manipulation before counter-productive responses of resource degradation hold sway.

Natural ecosystems progress towards maturity through ageing; this results in parsimony in the rate of resource use. This was evident in the studies of ash forest and of natural grassland with short-lived values of $\hat{U}_{\mathrm{U} / \mathrm{S}}=0.8$; trends with age were similar but the response time was shorter than with forest. Communities in a mature state are ideal for water harvesting in upland forests and in grassland on undulating country in the lowlands. Fire, however, reduces water availability in both communities. The wildfire of 1939 attained temperatures in excess of $300^{\circ} \mathrm{C}$; this interrupted successional progress (Craig, 1964) and resulted in a 
rejuvenated community of high vigour and much reduced water harvest (Langford, 1976; Kucerza, 1987). Control burns, designed to reduce fuel loads on the forest floor, are cooler and minimise damage to the overstorey thereby enabling the ageing trend to proceed. Water harvest is diminished, but not to the same extent as with rejuvenation although the loss of control on $\mathrm{E}_{\mathrm{S}}$ through regular litter removal will reduce streamflow. Fire in natural grassland led to a $30 \%$ increase in $\hat{U}_{\mathrm{U} / \mathrm{S}}$ to 1.0 and an equivalent reduction in streamflow that lasted for about one year (Dunin, 1989). Grazing affects the amount of water harvested through diminished soil water conservation. An absence of mulch and a rejuvenated sward in a grazed community of natural grassland have increased $\hat{U}_{\mathrm{U} / \mathrm{S}}$ to $90 \%$ of that for improved pasture (Dunin, 1970).

Intervention in natural ecosystems by species change in forestry and for pasture has resulted in higher productivity at the expense of water harvest. The paradox is that changed plant function which has been successful in delivering higher growth, fails to afford environmental protection because of loss of control on sediment and solute transport. For pine plantation, the danger of water contaminated with sediment tends to be associated with the establishment and harvesting phases. Hence, ensuring prudent planting and harvesting techniques is essential in protecting a water resource now diminished in quantity. Agricultural development is more complex; a persistent erosion hazard is compounded by a potential problem of solute transport with far reaching ramifications for both land and water conservation. River contamination, mainly with salt from agricultural sources, has become so pressing that community demands for reform in agricultural land management now have high priority. Achieving on-farm control of material transport while still maintaining profitable enterprises in food and fibre production has been a recurrent issue for decades but contemporary outbreaks of salinity and acidity, currently accelerating in farmland, have underlined the urgent need for a novel ecology that redresses conservation problems through high productivity (Downes, 1959).

Technological advances in crop and pasture agronomy for productivity and profit have been hailed as providing a buffer against deep drainage to ward off escalating problems of soil salinity and acidity (Singh et al., 2002). One of the present case studies demonstrates a $50 \%$ increase in productivity for a marginal change in buffering capacity against drainage. This lack of flow control can be attributed mainly to a shallow root zone associated with the suite of annual species used extensively in agricultural practice. A case for reinstating perennials in the agricultural landscape can be mounted on grounds of an extended root zone that serves the conservation cause with active growth in summer to control erosion and effective buffering against deep drainage implicated in degradation of both soil salinity and acidity. A series of Australian programmes and studies is under way to explore the role of perennials in reclaiming saline land, as in Montana, USA, with catchment revegetated by the herbaceous perennial legume lucerne, Medicago sativa (Miller et al., 1981). This species has been the focal point for herbaceous re-vegetation in Australian crop rotations with as much as a three-fold increase in soil water extraction over that by annual crops (Ward et al., 2001; Ridley et al., 2001). This removal of accrued subsoil water during the lucerne phase of the rotation provides drainage control akin to that of natural ecosystems (Dunin et al., 2001) without major compromise to crop yields (McCallum et al., 2001; Latta et al., 2001). Stemming the spread of salinity requires an exploitative phase of water use to deny groundwater accession and restore water table levels to pristine conditions. Woody plantations of either exotic or natural species are effective in eliminating groundwater recharge within their local zone of soil water extraction; lateral extension of uptake beyond the canopy drip line is minor (Stirzaker et al., 1999) and this extension is determined as the length equivalent of 1-2 times canopy height. Enhanced interception loss and rapid root penetration into subsoil are characteristic of plantations of exotic species, such as tagasaste (Lefroy et al., 2001) and eucalypts (White et al., 2002). In both of these studies, uptake of groundwater from the capillary fringe accelerated the process of groundwater reduction. Not all species are equally efficient in abstracting groundwater, which indicates species variation in tolerance to oxygen limitation for root functioning. However, any lowering of the local water table generates a lateral influence to reduce groundwater discharge. Evaluation of this effect has involved comparison of groundwater uptake by a plantation with rates of recharge below adjoining farmland on a hillslope discharging saline groundwater to streamflow (Dunin, 2002). In this study to restore the natural water balance, $\sim 20 \%$ of forest plantation area was optimal for arresting the spread of salinity so that reclamation of salt scalds could proceed. A generalised appraisal of the trade-off between crop productivity and drainage control by plantations offers a basis for assessing the potential for control of salinity across a range of terrain and geometry in groundwater flow (Stirzaker et al., 2002). These insights offer the ingredients of a novel ecology to balance competing demands in land management.

An integrated approach to water conservation is critical at the scale of the river basin where the balance in catchment outputs shifts towards plant productivity with downwards progression along a transect of reducing altitude and rainfall. Upland, the discharge of freshwater as perennial streamflow 
takes precedence over the competing industries of forestry and high country cattle grazing. Regulated rivers, diverted for both urban water supply and irrigation, require reliable flows of clean water. In the lowlands, contamination of the resource has become a problem through return flow from irrigation as well as through transport of materials in the meagre flows from semi-arid tributaries under dryland agriculture. Remedial action is directed at solute flows through hydraulic control of return flow from irrigation and urban discharge. Attention to sediment control in tributary flow is now being reinforced with biological measures to curtail salt flow. Progress in conservation and resolution of competing pressures may well be facilitated through the understanding gained in these case studies.

\section{Concluding remarks}

A generation of data acquisition on gaseous exchange is the basis of a simple conceptual framework to link plant growth with water use; this is critical for an understanding of contemporary issues of the effects of changes in land use on water resources. This framework identifies 11-17 distinguishing features of an ecosystem to describe plant function in the use of water, carbon and light resources for growth. A shift in the values of these features has been explored in four case studies of experimental catchments, in each of which outflows were altered by changes in ecology which improved plant productivity. Interest in these cases of hydrological change arises from a need to reconcile counterintuitive responses to changing plant productivity. Three cases of man's intervention for greater plant productivity have generated a range of hydrological responses but all threaten water conservation. The other case of wildfire had an intriguing outcome of reduced forest streamflow.

That greater growth demands increased water use is axiomatic in agronomy (Briggs and Shanz, 1914) but the hydrological outcome is generally a reduction in streamflow (Hewlett and Hibbert, 1967; Bosch and Hewlett, 1982). Yet, trebled pine productivity at Lidsdale was achieved without changes in annual evapotranspiration, $\mathrm{E}_{\mathrm{U} / \mathrm{S}}$, over that by the natural community of dry sclerophyll eucalypt forest. The interception loss, $\mathrm{E}_{\mathrm{I}}$, by pine $\left(5-10 \% \mathrm{P}_{\mathrm{G}}\right.$ ) was greater and accounted for the reduction in streamflow but fell far short of the necessary carbon assimilation to account for differences in annual growth rate. This can be explained as a phase difference in the annual patterns of $\mathrm{E}_{\mathrm{U} / \mathrm{S}}$; pine is better adapted to make effective use of soil water uptake, $\mathrm{E}_{\mathrm{U}}$, at low temperatures in winter and spring. A seasonal difference in plant function, $\mathrm{T}_{\mathrm{OPT}}$, between natural perennial pasture and improved annual pasture was critical in changing outflow following a trebling of pasture production. In this case, greater seasonal $\mathrm{E}_{\mathrm{U}}$ by the annual pasture in winter and spring exceeded that by natural grassland in summers generally deficient in rainfall. Thus, overland flow was reduced but the shallow root zone of the annual pasture, unable to cope with additional infiltration, led to accelerated deep drainage as a hydrological change which beset the agricultural environment with salt in transition. Efforts at enhanced agricultural production have been rewarded with productivity increases that can be rated as $25-50 \mathrm{~mm}$ of incremental $\mathrm{E}_{\mathrm{U}}$ per $\mathrm{tha}^{-1}$ of wheat grain harvest. These greater levels of uptake do not translate into commensurate increases in $\mathrm{E}_{\mathrm{U} / \mathrm{S}}$ because of the offsetting effects of soil water conservation afforded by additional herbage in suppressing $\mathrm{E}_{\mathrm{S}}$. Instances where additional $\mathrm{E}_{\mathrm{U}}$ is compensated by reduced $\mathrm{E}_{\mathrm{S}}$ may lead to zero mitigation deep drainage in the presence of increased growth. The case for restoring the natural water balance through ever-increasing productivity of annual ecosystems lacks hydrological support.

That streamflow falls after forest wildfire contradicts conventional wisdom on forest clearing (Bosch and Hewlett, 1982) and even a previous report on eucalypt burning (Brown, 1972). The physiological explanation of this anomaly may reflect the control of transpiration by trees over 100 years old (Watson et al., 1999). Juvenile development of eucalypts from seedlings can proceed with high $\hat{U}_{\mathrm{U}}$, in contrast to early phases of rejuvenation through epicormic regrowth. This is a timely reminder of the virtue, for water harvesting, of moribund plant communities although management to preserve the mature state with limited function still provokes controversy.

A policy of integrated catchment management must define areas of water harvest involving the preservation of natural ecosystems with assured fire protection. For local water harvest, lowland, natural grassland free of grazing and fire can emulate the role of upland mature forest. Multiple land use with plant production prioritised will reduce the quantity of water, perhaps with a deterioration in water quality in respect of solutes and material transport of sediment. Restoration of the natural water balance may be critical in remediation; to this end, reinstatement of perennials in agricultural systems is advocated. The challenge still remains to optimise the productivity of a combination of perennials and annuals to produce the required outflow control.

\section{References}

Allen, R.G., Pereira, L.S., Raes, D. and Smith, M., 1998. Crop evaporation-Guidelines for computing crop water requirements. FAO Irrigation and Drainage Paper 56. U.N. Food and Agriculture Organisation, Rome, Italy. 
Aston., A.R., 1979. Rainfall interception by eight small trees. $J$. Hydrol., 48, 71-87.

Aston, A.R. and Dunin, F.X., 1980. Land-Use Hydrology: Shoalhaven, New South Wales. J. Hydrol., 42, 383-396.

Attiwill, P.M., 1979. Nutrient cycling in a Eucalyptus obliqua (L. Herit) forest: Growth, biomass and net primary production. Aust. J. Bot., 27, 439-458.

Baldocchi, D.D., Verma, S.B. and Rosenburg, N.J., 1985. Water use efficiency in a soybean field: influence of plant water stress. Agr. Forest Meteorol., 34, 53-65.

Bettanay, E., Blackmore, A.V. and Hingston, F.J., 1964. Aspects of the hydrological cycle and related salinity in the Belka Valley, Western Australia. Aust. J. Soil Res., 2, 187-210.

Bosch, J.M. and Hewlett, J.D., 1982. A review of catchment experiments to determine the effect of vegetation changes on water yield and evapotranspiration. J. Hydrol., 55, 3-22.

Boughton, W.C., 1970. Effects of land management on quantity and quality of available water resources. Australian Water Resources Council Research Project 68/2. University of New South Wales Water Research Laboratory, Manly Vale, NSW, Report No. 120.

Briggs, L.J. and Shantz, H.J., 1914. Relative water requirement of plants. J. Agr. Sci. 3, 1-63.

Brookes, J.D. and Turner, J.S., 1964. Hydrology and Australian forest catchments. In: Water resources, use and management, Melbourne Univ. Press, Australia. 390-398.

Brown, J.A.H., 1972. Hydrologic effects of a bushfire in a catchment in southeastern New South Wales. J. Hydrol., 17, 77-96.

Cornish, P.M. and Vertessy, R.A., 2001. Forest age-induced changes in evapotranspiration and water yield in a eucalypt forest. J. Hydrol., 242, 43-63.

Craig, F.G., 1968. Effect of fire on physical properties of soil. $\mathrm{PhD}$ Thesis, Forestry School, University of Melbourne. Australia.

de Laine, R.J. and Vasey, G.H., 1961. A survey of farm water supplies in central parts of Victoria,. University of Melbourne, Australia. 56-57.

Denmead, O.T., 1984. Plant physiological methods for studying evapotranspiration: problems of telling the forest from the trees. Agr. Water Manage., 8, 167-189.

Denmead, O.T. and Shaw, R.F., 1962. Availability of soil water to plants as affected by soil moisture and meteorological conditions. Agron. J., 54, 385-390.

Denmead, O.T., Dunin, F.X., Leuning, R. and Raupach, M.R, 1996. Measuring and modeling soil evaporation in wheat crops. Phys. Chem. Earth, Special Issue. European Geophysical Society, Germany. 2-5.

De Wit, C.T., 1958. Transpiration and crop yields. Versl.Landbouwk. Onderz. 64, 1-88. Inst. Biol. Chem. Res. on Field Crops and Herbage. Wageningen, The Netherlands.

Downes, R.G., 1958. Land management problems following disturbance of the water balance in environments of Victoria. $7^{\text {th }}$ Technical Meeting Int. Un. Conservation of Nature and Resources, Athens, Greece. P. 1-19.

Downes, R.G., 1959. The ecology and prevention of soil erosion. In: Biogeography and Ecology in Australia. Junk, den Haag, The Netherlands.

Downes, R.G., 1972. Water catchment management and recreational use. Water Research Foundation of Australia Report No 37. p. 1.1-1.6.

Dunin, F.X., 1965. The effect of vegetative change on parameters for estimating runoff near Bacchus Marsh, Victoria. Civil Eng. Trans. Inst. Eng. Aust., CE7, 16-22.

Dunin, F.X., 1970. Changes in water balance components with pasture management in southeastern Australia. J. Hydrol., 10, 99-102.
Dunin, F.X., 1976. Changes in the water balance with land modification in Southern Australia. In: Watershed Management on Range and Forest Lands, H.F. Heady, D.H. Falkenborg and J. P. Riley (Eds.). Proc. Fifth Workshop United States/Australia Rangelands Panel Boise, Idaho, June 1975. Utah State University: Logan, USA. 157-163.

Dunin, F.X., 1987. Run-off and drainage from grassland catchments. In: Ecosystems of the world 17B, managed grasslands, B. analytical studies, R.W. Snaydon (Ed.). Elsevier, Amsterdam, The Netherlands. 205-213.

Dunin, F.X., 2002. Integrating agroforestry and perennial pastures to mitigate water logging and secondary salinity. Agr. Water Manage., 53, 259-270.

Dunin, F.X. and Downes, R.G., 1962. The effect of subterranean clover and Wimmera ryegrass in controlling surface runoff from four-acre catchments near Bacchus Marsh, Victoria. Aust. J. Exp. Agr. Anim. Husb., 2, 148-152.

Dunin, F.X. and Reyenga, W., 1978, Evaporation from a Themeda grassland. 1. Controls imposed on the process in a sub-humid environment. J. Appl. Ecol., 15, 317-325.

Dunin, F.X. and Aston, A.R., 1984. The development and proving of models of large scale evapotranspiration: an Australian study. Agr. Water Manage., 8, 305-323.

Dunin, F.X., McIlroy, I.C. and O'Loughlin, E.M., 1985. A lysimeter characterization of evaporation by eucalypt forest and its representativeness for the local environment. In: The forest atmosphere interaction, B.B.Hicks and B.A. Hutchison (Eds.). Proc. Forest Environ. Measurements Conf., Oak Ridge, Tennessee, 1983. Riedel, Dortrecht, Germany. 271-291.

Dunin, F.X., O'Loughlin, E.M. and Reyenga, W., 1988. Interception loss from eucalypt forest: lysimeter determination of hourly rates for long term evaluation. Hydrol. Process., 2, 315-329.

Dunin, F.X., Williams, J., Verburg, K. and Keating, B.A., 1999. Can agricultural management emulate natural ecosystems in recharge control in south-eastern Australia? Agroforest. Syst., 45, 343-364.

Dunin, F.X., Smith, C.J., Zegelin, S., Leuning, R., Denmead, O.T. and Poss, R., 2001. Water balance changes in a crop sequence with lucerne. Aust. J. Agr. Res., 52, 247-261.

Dunn, G.M. and Connor, D.J., 1993. An analysis of sap flow in mountain ash (Eucalyptus regnans) forests of different age. Tree Physiol., 13, 321-336.

Eagleson, P.A., 1982. Ecological optimality in water-limited natural vegetation soil-vegetation systems. 1. Theory and Hypothesis. Water Resour. Res., 18, 325-340.

Feller, M.C., 1981. Water balances in Eucalyptus regnans, E. obliqua and pine forests in Victoria. Aust. Forestry, 44, 153-161.

Freeze, R.A., 1972. The role of subsurface flow in generating surface runoff. 2. Upstream source areas. Water Resour. Res., 8, 1271-1283.

Gash, J.H.C., 1979. An analytical model of rainfall interception by forests. Quart. J. Roy. Meteorol. Soc., 105, 43-55.

Gash, J.H.C. and Stewart, J.B., 1977. The evaporation from Thetford Forest in 1975. J. Hydrol., 35, 385-396.

Groves, R.H., 1965. Growth of Themeda australis tussock grassland at St. Albans, Victoria. Aust. J. Bot., 13, 291-302.

Groves, R.H., 1974. Growth of Themeda australis in response to firing and mowing. Division of Plant Industry, Field Station Record No. 13, 1-7. CSIRO, Australia.

Hamblin, A.P. and Kyneur, G., 1994. Trends in Wheat Yields and Soil Fertility in Australia. Bureau of Resource Sciences, Australian Government Service, Canberra.

Hatch, M.D. and Slack, C.R., 1966. Photosynthesis by sugar-cane leaves. A new carboxylation reaction and the pathway to sugar formation. Biochem. J., 101, 103-111. 
Hatch, M.D., Slack, C.R. and Johnson, H.S., 1967. Further studies on a new pathway of photosynthetic carbon dioxide fixation in sugar-cane and its occurrence in other plant species. Biochem. J., 102, 417-422.

Hewlett, J.D. and Hibbert, A.R., 1967. Factors affecting the response of small watersheds to precipitation in humid areas. In: International Symposium on Forest Hydrology, The Pennsylvania State Univ., 29 August-10 September 1965, W.E. Sopper and H.W. Lull (Eds.), Pergamon, Oxford, UK. 275-290.

Jayasuriyra, M.D.A., Dunn, G., Benynon, R. and O'Shaughnessy, P.J., 1993. Some factors affecting water yield from mountain ash (Eucalyptus-regnans)-dominated forests in South-East Australia. J. Hydrol., 150, 345-367.

Latta, R.A., Blacklowe, L.J. and Cocks, P.S., 2001. Comparative water use, soil water, pasture production and crop yields in phase farming systems with lucerne and annual pasture in Western Australia. Aust. J. Agr. Res., 52, 295-304.

McCallum, M.H., Connor, D.J. and O'Leary, G.J., 2001. Water use by lucerne and effect on crops in the Victorian Wimmera. Aust. J. Agr. Res., 52, 193-202.

McNaughton, K.G. and Jarvis, P.G., 1983. Predicting the effects of vegetation change on transpiration and evaporation. In: Water deficits and plant growth, T.T. Kozlowski (Ed.), Vol. VII. Academic Press, New York, USA. 1-47.

Miller, M.R., Brown, P.J, Donovan, J.J., Beratino, R.N., Sondoregger, J.L. and Schmidt, F.A., 1981. Saline seep development and control in the North American Great Plainshydrological aspects. Agr. Water Manage., 4, 115-141.

Monteith, J.L., 1964. Evaporation and Environment. The State and Movement of Water in Living Organisms. In: Symp. Soc. Exp. Biol. 19, CUP, Cambridge, UK. 205-234.

Moore, R.M., 1970. Australian Grasslands. In: Australian grasslands, R.M. Moore (Ed.), ANU Press, Canberra, Australia. $87-100$.

Passioura, J.B., 1973. Sense and nonsense in crop simulation. $J$. Aust. Inst. Agr. Sci., 39, 181-183.

Peck, A.J., 1978. Salinization of non-irrigated soils and associated streams: a review. Aust. J. Soil Res., 16, 157-168.

Philip, J.R., 1957. Evaporation, moisture and heat fields in the soil. J. Meteorol., 14, 354-366.

Philip, J.R., 1967. The second stage of drying of soil. J. Appl. Meteorol., 6, 581-582.

Pilgrim, D.H., Doran, D.G., Rowbottom, I.A., Mackay, S.M. and Tjendana, J., 1982. Water balance and runoff characteristics of mature and cleared pine and eucalypt catchments at Lidsdale, New South Wales. In: The first national symposium on forest hydrology, Melbourne 1982, E.M. O'Loughlin and L.K. Bren (Eds.), Inst.Eng. and Australian Forestry Council, Canberra, Australia. 103-117.

Priestley, C.B.H. and Taylor, R.J., 1972. On the assessment of surface heat flux and evaporation using large scale parameters. Mon. Weather Rev., 100, 81-92.

Rawson, H.M., Begg, J.E. and Woodward, R.M., 1977. The effect of atmospheric humidity on photosynthesis, transpiration and water use efficiency of leaves of several plant species. Planta, 134, 5-10.

Ridley, A.M., Christy, B., Dunin, F.X., Haines, P.J., Wilson, K.F. and Ellington, A., 2001. Lucerne in crop rotations on the Riverine Plains: (1) the soil water balance. Aust. J. Agr. Res., 52, 263-277.

Ritchie, J.T., 1981. Water dynamics in the soil-plant-atmosphere system. Plant Soil, 58, 81-96.

Roberts, S., Vertessy, R.A. and Grayson, R.B., 2000. Transpiration from Eucalyptus sieberi (L, Johnson) forests of different ages. Forest Ecol. Manage., 143, 153-161.
Rutter, A.J., 1967. An analysis of evaporation from a stand of Scots Pine. In: International symposium on forest hydrology, Pennsylvania State Univ., 29 August-10 September 1965, W.E. Sopper and H.W. Lull (Eds.), Pergamon Press: Oxford, UK. 403-417.

Rutter, A.J., 1968. Water consumption by forests. In: Water deficits and plant growth, T.T. Kozlowski (Ed.), Vol. 2. Academic Press, New York, USA. 23-84.

Rutter, A.J., Kershaw, K.A., Robbins, P.C. and Morton, A.J., 1972. A predictive model of rainfall interception by forests. I. Derivation of the model from observations in a plantation of Corsican Pine. Agr. Meteorol., 9, 367-384.

Sadras, V.O., Whitfield, D.M. and Connor, D.J., 1991. Transpiration efficiency in crops of semi-dwarf and standardheight sunflower. Irrig. Sci., 12, 87-91.

Sinclair, T.S. and Muchow, R.C., 1999. Radiation use efficiency. Adv. Agron. 65, 215-265.

Singh, D.K., Bird, P.R. and Saul, G.R., 2003. Maximising the use of soil water by herbaceous species in the high rainfall zone of southern Australia: a review. Aust. J. Agr. Res., 54, 677-691.

Smith, C.J., Dunin, F.X., Zegelin, S.J. and Poss, R., 1998. Nitrate leaching from a riverine clay soil under cereal rotation. Aust. J. Agr. Res., 49, 379-389.

Smith, C.J., Dunin, F.X., Poss, R. and Angus, J.F., 2000. Nitrogen budget of wheat growing on a riverine clay soil. Aust. J. Agr. Res., 51, 867-876.

Smith, M.K., Watson, K.K. and Pilgrim, D.H., 1974. A comparative study of the hydrology of radiata pine and eucalypt forests at Lidsdale, New South Wales. Civil Eng. Trans. Inst. Eng. Aust., 16, 82-86.

Stewart, J.B., 1988. Modelling surface conductance of pine forest. Agr. For. Meteorol., 43, 19-35.

Stewart,J.B. and Thom,A.S., 1973. Energy budgets in pine forest. Quart. J. R. Meteorol. Soc., 99, 154-170.

Stirzaker, R.J., Cook, F.J. and Knight, J.H., 1999. Where to plant trees on cropping land for control of dryland salinity: some approximate solutions. Agr. Water Manage., 39, 115-133.

Stirzaker, R.J., Lefroy, E.C. and Ellis, T.W., 2002. An index for quantifying the trade-off between drainage and productivity in tree-crop mixtures. Agr. Water Manage., 53, 187-199.

Tanner, C.B. and Sinclair, T.R., 1983. Efficient water use in crop production: research or re-search? In: Limitations to efficient water use in crop plants, H.M. Taylor, W.R. Jordon and T.R. Sinclair (Eds.), Crop Sci. Soc. Amer., Madison, Wisconsin, USA. $1-27$

Walker, G.R., Zhang, L., Ellis, T.W., Hatton, T.J. and Petheram, C., 2002. Estimating impacts of changed land use on recharge: a review of modelling and other approaches appropriate for management of dryland salinity. Hydrogeol. J., 10, 68-90.

Tuzet, A., Perrier, A. and Leuning, R., 2003. A coupled model of stomatal conductance, photosynthesis and transpiration. Plant, Cell Environ., 26, 1097-1116.

Ward, P.R., Dunin, F.X. and Micin, S.F., 2001. Water balance of annual and perennial pastures on a duplex soil in a Mediterranean environment. Aust. J. Agr. Res., 52, 247-262.

Watson, F.G.R., Vertessy, R.A. and Grayson, R.B., 1999. Largescale modelling of forest hydrological processes and their longterm effect on water yield. Hydrol. Process. 13, 689-700.

White, D.A., Dunin, F.X., Turner, N.C., Ward, B.H. and Galbraith, J.H., 2002. Water use by contour-planted belts of trees comprised of four Eucalyptus species. Agr. Water Manage., 53, 133-152.

Whitfield, D.M. and Smith, C.J., 1989. Effect of irrigation and nitrogen on growth, light interception and efficiency of light conversion in wheat. Field Crop. Res. 20, 279-295.

Wong, S.C., Cowan, I.R. and Farquhar, G.D., 1979. Stomatal conductance correlates with photosynthetic capacity. Nature 282, 424-426. 